Review

\title{
Marine Peptides and Their Anti-Infective Activities
}

\author{
Hee Kyoung Kang ${ }^{1}$, Chang Ho Seo ${ }^{2}$ and Yoonkyung Park ${ }^{1,3, *}$
}

1 Department of Biomedical Science, Chosun University, Gwangju 501-759, Korea;

E-Mail: hkkang129@gmail.com

2 Department of Bioinformatics, Kongju National University, Kongju 314-701, Korea;

E-Mail: chseo@kongju.ac.kr

3 Research Center for Proteineous Materials, Chosun University, Gwangju 501-759, Korea

* Author to whom correspondence should be addressed; E-Mail: y_k_park@ @chosun.ac.kr; Tel.: +82-62-230-6854; Fax: +82-62-225-6758.

Academic Editor: Miguel O. Mitchell

Received: 11 November 2014 / Accepted: 1 January 2015 / Published: 16 January 2015

\begin{abstract}
Marine bioresources are a valuable source of bioactive compounds with industrial and nutraceutical potential. Numerous clinical trials evaluating novel chemotherapeutic agents derived from marine sources have revealed novel mechanisms of action. Recently, marine-derived bioactive peptides have attracted attention owing to their numerous beneficial effects. Moreover, several studies have reported that marine peptides exhibit various anti-infective activities, such as antimicrobial, antifungal, antimalarial, antiprotozoal, anti-tuberculosis, and antiviral activities. In the last several decades, studies of marine plants, animals, and microbes have revealed tremendous number of structurally diverse and bioactive secondary metabolites. However, the treatments available for many infectious diseases caused by bacteria, fungi, and viruses are limited. Thus, the identification of novel antimicrobial peptides should be continued, and all possible strategies should be explored. In this review, we will present the structures and anti-infective activity of peptides isolated from marine sources (sponges, algae, bacteria, fungi and fish) from 2006 to the present.
\end{abstract}

Keywords: marine organisms; anti-infective peptides; antimicrobial; antifungal; antiviral 


\section{Introduction}

Marine organisms are important sources of bioactive molecules that have been used to treat various diseases. Unusual marine environments are associated with chemical diversity, leading to a resource of novel active substances for the development of bioactive products [1-4].

Oceans, which cover more than $70 \%$ of the earth's surface, represent an enormous resource for the discovery of potential therapeutic agents. Over the last several decades, numerous compounds have been found in marine organisms with interesting pharmaceutical activities [1,5,6]. Therefore, marine organisms are thought to be a potential source of essential and novel biologically active substances for the development of therapeutics. In particular, marine peptides have attracted a great deal of attention due to their potential effects in promoting health and reducing disease.

Despite tremendous progress in medicine, infectious diseases caused by bacteria, fungi, and viruses are still a major threat to public health. Their impact is particularly large in developing countries due to the lack of access to medicines and the emergence of widespread drug resistance. Increasing numbers of microbial pathogens that have acquiring antibiotic-resistance have resulted in the increase demand for novel and effective antimicrobial compounds. In particular, studies evaluating the anti-infective actions of marine peptides are attracting increased researchers' interest, and marine peptides have been increasingly considered as anti-infective drugs. The diversity of the marine environment has provided a unique source of bioactive chemical compounds that could lead to potential new drugs candidates.

Marine peptides are specific protein fragments that in addition to acting as sources of nitrogen and amino acids have numerous potential physiological functions [7]. These peptides have been obtained from algae, fish, mollusk, crustacean, crab and marine bacteria and fungus. Bioactive marine peptides based on their structural properties, amino acid composition and sequences have been shown to display a variety of bioactivities such as anti-tumor, antiviral, anticoagulant, antioxidant, immunoinflammatory effects, and other medicinal properties [1,2,8,9].

In this review, we will present the structures and anti-infective activity of peptides isolated from the main marine organisms and microorganisms of interest (sponges, algae, bacteria, fungi and fish) from 2006 to the present.

\section{Marine Organisms and Microorganisms}

\subsection{Sponges}

Sponges are sessile marine filter feeders that have developed efficient defense mechanisms against foreign attackers such as viruses, bacteria, or eukaryotic organisms. Marine sponges are one of the richest sources of pharmacologically-active chemicals in marine environments. It has been suggested that many of the bioactive secondary metabolites isolated from sponges are produced by functional enzyme clusters, which originated from the sponges and their associated microorganisms [10,11]. More than 5300 different products have been identified in sponges and their associated microorganisms, and more than 200 new metabolites from sponges are reported each year [10]. As infectious microorganisms evolve and develop resistance to existing pharmaceuticals, the marine sponge provides novel leads against bacterial, viral, fungal and parasitic diseases. Many marine natural products have successfully advanced to the late stages of clinical trials. The chemical diversity of sponge products is remarkable. In 
addition to the unusual nucleosides, bioactive terpenes, sterols, peptides, alkaloids, fatty acids, peroxides, and amino acid derivatives (all of them frequently halogenated) have been described in sponges. The early appearance of sponges in evolution has given them a lot of time for the development of an advanced chemical defense system. The synthesis of secondary metabolites is regulated, depending on conditions that the sponge experiences. The huge variety of secondary metabolites in marine sponges and the complexity of the compounds and their biosynthetic pathways can be regarded as an indication of their importance for survival. As infectious microorganisms evolve and develop resistance to existing pharmaceuticals, marine sponges provide novel leads against bacterial, fungal, and viral diseases $[10,11]$.

\subsection{Algae}

Algae are very simple chlorophyll-containing organisms composed of one cell or grouped together in colonies or as organisms with many cells, sometimes collaborating together as simple tissues [12]. Algae are heterogeneous group of plants with a long fossil history. Two major types of algae have been identified. Macroalgae (seaweeds) occupy the littoral zone, whereas microalgae are found in both benthic and littoral habitats, as well as throughout the ocean waters as phytoplankton [13]. Phytoplankton include numerous organisms, including diatoms (Bacillariophyta), dinoflagellates (Dinophyta), green and yellow-brown flagellates, and blue-green algae (cyanobacteria). As photosynthetic organisms, this group plays a key role in the productivity of oceans and constitutes the basis of the marine food chain [12].

Marine algae produce a cocktail of metabolites with interesting biological activities, including anti-infective, anti-inflammatory and anti-proliferative, and with potential commercial value [14-17]. Structures exhibited by these compounds go from acyclic entities with a linear chain to complex polycyclic molecules. Their medical and pharmaceutical applications have been investigated for several decades [18].

Marine macroalgae have been used as foods, especially in China and Japan, and as crude drugs for the treatment of many diseases, such as iodine deficiency (goiter, Basedow's disease, and hyperthyroidism). Some seaweeds have also been used as a source of vitamins, treatment for various intestinal disorders, such as vermifuges, and as hypocholesterolemic and hypoglycemic agents [19].

Marine eukaryotic microalgae are known to produce numerous useful products, but have attracted little attention in the search for novel anti-infective compounds. Current reports mainly concern diatoms and cyanobacteria [20].

Diatoms are ubiquitous and constitute an important group within the phytoplankton community, as well as making an important contribution to the total marine primary production. These microalgae exhibit a characteristic golden-brown color, due to a high amount of xanthophyll fucoxanthin, which plays a major role in the light-harvesting complex of photosystems. In the water column, diatoms are exposed to rapidly varying light intensities. Diatoms produce an array of biologically active metabolites, many of which have been ascribed to a form of chemical defense, and which may have potential as candidate marine drugs [21].

Blue-green algae (cyanobacteria) show many structural features that are in common with bacteria. However, they are classified with algae because they contain chlorophyll a and related compounds. These algae are ancient photosynthetic prokaryotic organisms that produce biologically active 
secondary metabolites with diverse chemical structures such as nitrogenous compounds and cyclic polyethers [17]. Cyanobacteria may have evolved this extensive capacity to produce bioactive molecules because they are prokaryotes that have developed beyond a microscopic lifestyle, and hence require an arsenal of defensive substances to ward off predation by diverse macrograzers. Recently, several marine cyanobacterial natural products have been the focus of much attention, due to their intriguing structures and exciting biological activities [22].

\subsection{Microorganism}

Microorganisms have been the source of many valuable compounds in medicine, the pharmaceutical industry, and agriculture; however, most of these organisms are derived from terrestrial habitats. After intensive studies on terrestrial microorganisms, attention has now been focused on other ecosystems, such as the sea. Marine microorganisms, including bacteria and fungi, are rich sources of chemical products. Marine microorganisms are a promising new source of a large number of biologically active products [23-26]. Some of these marine species survive in a stressful habitat, under cold, lightless, and high-pressure conditions. These factors have resulted in the development of unique metabolisms, which result in the production of novel metabolites that differ from terrestrial organisms. Thus, marine microorganisms offer a wonderful resource for the discovery of new compounds with interesting biological activities, including antimicrobial, antifungal, anti-protozoan, anti-tuberculosis, and antiviral properties [27,28]. Thus far, only a small number of microorganisms have been investigated for their bioactive metabolites; however, a large number of active substances have been isolated, some of which feature unique structural skeletons.

\subsection{Fish}

Fishery products, including underutilized fish, jellyfish, and mollusks, also contain diverse and novel compounds. Some of these function as hypotensive agents, cardio-protective substances, muscle relaxants, and antimicrobial, antiviral, and anti-tumor agents [2,29,30].

Fish peptides exhibit broad-spectrum antimicrobial activity, killing both fish and human pathogens. These peptides have immunomodulatory effects, and the genes encoding these are highly responsive to microbes and innate immunostimulatory molecules. Recent research has demonstrated that some of the unique properties of fish peptides, including their ability to act even at very high salt concentrations, make them good potential targets for development as therapeutic antimicrobials [2,29,30].

In this review, we have surveyed peptides derived from marine sponges, algae, bacteria, fungi, and fish that have shown efficacy or activity against infectious and parasitic diseases, including bacterial, viral, fungal and protozoan infections.

\section{Anti-Infective Marine Peptides}

Table 1 presents new anti-infective peptides reported from 2006 to the present, along with their composition, source of origin, and reported bioactivity. 
Table 1. List of anti-infective peptides from diverse marine sources.

\begin{tabular}{|c|c|c|c|c|c|}
\hline Activity & $\begin{array}{l}\text { Name of } \\
\text { Peptide }\end{array}$ & $\begin{array}{c}\text { Source of Original } \\
\text { Peptides } \\
\end{array}$ & $\begin{array}{c}\text { Pharmacologic } \\
\text { Activity } \\
\end{array}$ & $\begin{array}{c}\text { Inhibition } \\
\text { Concentrations } \\
\end{array}$ & References \\
\hline Antibacterial & Aurelin (1) & Jellyfish: Aurelia aurita & $\begin{array}{c}\text { Escheichia coli } \\
\text { inhibition } \\
\end{array}$ & $7.7 \mu \mathrm{g} / \mathrm{mL}$ (MIC) & [31] \\
\hline Antibacterial & Arenicin-1 (2) & $\begin{array}{c}\text { Polychaete: } \\
\text { Arenicola marina }\end{array}$ & $\begin{array}{c}\text { Pseudomomas } \\
\text { aeruginosa and } \\
\text { Staphylococcus aureus } \\
\text { inhibition } \\
\end{array}$ & $2 \mu \mathrm{g} / \mathrm{mL}$ (MIC) & {$[32,33]$} \\
\hline Antibacterial & Tauramamide (3) & $\begin{array}{c}\text { Bacterium: Brevibacillus } \\
\text { laterosporus }\end{array}$ & $\begin{array}{c}\text { Enterococcus sp. } \\
\text { inhibition }\end{array}$ & $0.1 \mu \mathrm{g} / \mathrm{mL}$ (MIC) & {$[34]$} \\
\hline Antibacterial & Hepcidin (4) & $\begin{array}{c}\text { Fish: Oreochromis } \\
\text { mossambicus }\end{array}$ & $\begin{array}{c}\text { Listeria monocytogenes, } \\
\text { S. aureus, and } \\
\text { Enterococcus faecium } \\
\text { inhibition } \\
\end{array}$ & 50-100 $\mu \mathrm{g} / \mathrm{mL}(\mathrm{MIC})$ & {$[35]$} \\
\hline Antibacterial & Scygonadin (5) & Mud crab: Scylla serrata & $\begin{array}{l}\text { E. coli, } P \text {. aeruginosa, } \\
\text { S. aureus, Streptococcus } \\
\text { pyogenes inhibition }\end{array}$ & $50-100 \mu \mathrm{g} / \mathrm{mL}$ (MIC) & {$[36,37]$} \\
\hline Antibacterial & Tunichromes (6) & Ascidian: Ascidia nigra & $\begin{array}{c}\text { Enterococcus } \mathrm{sp} . \\
\text { inhibition } \\
\end{array}$ & $0.1 \mu \mathrm{g} / \mathrm{mL}$ (MIC) & {$[38,39]$} \\
\hline Antibacterial & $\begin{array}{c}\text { Bacillistatins } 1 \\
(\mathbf{7}), 2(\mathbf{8})\end{array}$ & $\begin{array}{c}\text { Bacterium: } \\
\text { Bacillus silvestris }\end{array}$ & $\begin{array}{c}\text { Streptococcus. } \\
\text { pneumonia inhibition }\end{array}$ & $0.5-2 \mu \mathrm{g} / \mathrm{mL}\left(\mathrm{GI}_{50}\right)$ & {$[40]$} \\
\hline Antibacterial & $\begin{array}{l}\text { Nacardiopsis } \\
\text { thiopeptide } \\
\text { TP-1161 (9) }\end{array}$ & $\begin{array}{c}\text { Bacterium: } \\
\text { Nocardiopsis sp }\end{array}$ & $\begin{array}{c}\text { Vancomycin-resistant } \\
\text { Enterococcus faecium } \\
\text { inhibition }\end{array}$ & $1 \mu \mathrm{g} / \mathrm{mL}$ (MIC) & [41] \\
\hline Antibacterial & $\begin{array}{l}\text { Centrocins } 1 \\
(\mathbf{1 0}), 2 \text { (11) }\end{array}$ & $\begin{array}{c}\text { Sea urchin: } \\
\text { Strongylocentrotus } \\
\text { droebachiensis }\end{array}$ & $\begin{array}{c}\text { Corynebacterium } \\
\text { glutamicum, S. aureus, } \\
\text { Listonella anguillarum, } \\
\text { E. coli inhibition }\end{array}$ & $1.3-5 \mu \mathrm{M}\left(\mathrm{IC}_{50}\right)$ & {$[42]$} \\
\hline Antibacterial & Halocyntin (12) & $\begin{array}{c}\text { Ascidian: Halocynthia } \\
\text { papillosa }\end{array}$ & $\begin{array}{l}\text { Micrococcus luteus, } \\
\text { Bacillus megaterium, } \\
\text { Aerococcus viridans, } \\
\text { S. aureus, Enterococcus } \\
\text { faecalis inhibition }\end{array}$ & $0.39-50 \mu \mathrm{M}(\mathrm{MBC})$ & [43] \\
\hline Antibacterial & Papillosin (13) & $\begin{array}{c}\text { Ascidian: Halocynthia } \\
\text { papillosa }\end{array}$ & $\begin{array}{c}\text { M. luteus, } \\
\text { B. megaterium, } \\
\text { Aerococcus viridans, } \\
\text { S. aureus, Enterococcus } \\
\text { faecalis inhibition }\end{array}$ & $\begin{array}{c}0.05-6.25 \mu \mathrm{M} \\
(\mathrm{MBC})\end{array}$ & [43] \\
\hline Antibacterial & Hyastain (14) & $\begin{array}{l}\text { Spider crab: } \\
\text { Hyas araneus }\end{array}$ & $\begin{array}{c}\text { E. coli, } \\
\text { Corynebacterium } \\
\text { glutamicum, } \text { S. aureus } \\
\text { inhibition }\end{array}$ & $0.4-12.5 \mu \mathrm{M}(\mathrm{MIC})$ & [44] \\
\hline Antibacterial & Indigoidine (15) & $\begin{array}{c}\text { Bacterium: } \\
\text { Phaeobacter sp. }\end{array}$ & $\begin{array}{l}\text { Vibrio fischeri } \\
\text { inhibition }\end{array}$ & ND & {$[45]$} \\
\hline
\end{tabular}


Table 1. Cont.

\begin{tabular}{|c|c|c|c|c|c|}
\hline Antibacterial & $\begin{array}{c}\text { Unnarmicins A } \\
\text { (16), C (17) }\end{array}$ & $\begin{array}{c}\text { Bacterium: } \\
\text { Photobacterium sp. }\end{array}$ & $\begin{array}{c}\text { Pseudovibrio sp. } \\
\text { inhibition }\end{array}$ & 7-18 ㅆg/disk (disk) & {$[46]$} \\
\hline Antibacterial & $\begin{array}{l}\text { Ngercheumicins } \\
\text { A-D (18-21) }\end{array}$ & $\begin{array}{c}\text { Bacterium: } \\
\text { Photobacterium sp. }\end{array}$ & $\begin{array}{c}\text { Gram negative strain } \\
\text { inhibition } \\
\end{array}$ & ND. & [47] \\
\hline Antibacterial & $\begin{array}{l}\text { Solonamidine A } \\
\text { (22), B (23) }\end{array}$ & $\begin{array}{c}\text { Bacterium: } \\
\text { Photobacterium sp }\end{array}$ & $\begin{array}{c}\text { S. aureus, } \\
\text { Methicillin-resistant } \\
\text { S. aureus (MRSA) } \\
\quad \text { inhibition }\end{array}$ & ND. & [48] \\
\hline Antibacterial & $\begin{array}{l}\text { Cyclo-peptides } \\
\text { (24) }\end{array}$ & $\begin{array}{c}\text { Bacterium: } \\
\text { Pseudomonas sp. }\end{array}$ & $\begin{array}{c}\text { S. aureus, M. luteus, } \\
\text { B. subtilis, E. coli, } \\
\text { V. anguillarum inhibition }\end{array}$ & ND & [49] \\
\hline Antibacterial & $\begin{array}{l}\text { Ariakemicins A } \\
\text { (25), B (26) }\end{array}$ & $\begin{array}{c}\text { Bacterium: } \\
\text { Rapidithrix sp. }\end{array}$ & $\begin{array}{l}\text { Brevibacterium sp., } \\
\text { S. aureus, B. subtilis } \\
\text { inhibition }\end{array}$ & $\begin{array}{c}0.46-80 \mu \mathrm{g} / \mathrm{mL} \\
(\mathrm{MIC})\end{array}$ & {$[50]$} \\
\hline Antibacterial & Damicornin (27) & $\begin{array}{l}\text { Coral: Pocillopora } \\
\text { damicorins }\end{array}$ & $\begin{array}{l}\text { M. luteus, B. megaterium, } \\
\text { S. aureus, Brevibacterium } \\
\text { stationis, Microbacterium } \\
\text { maritypicum, Fusarium } \\
\text { oxysporum inhibition } \\
\end{array}$ & $1.25-20 \mu \mathrm{M}(\mathrm{MIC})$ & {$[51]$} \\
\hline Antibacterial & Clavanis (28) & Tunicate: Styela clava & $\begin{array}{c}\text { S. aureus, Klebsiella } \\
\text { pneumonia, } P \text {. aeruginosa } \\
\text { inhibition }\end{array}$ & ND & {$[52]$} \\
\hline Antibacterial & $\begin{array}{l}\text { Cadiolides C-F } \\
\qquad(\mathbf{2 9}-\mathbf{3 2})\end{array}$ & $\begin{array}{c}\text { Tunicate: } \\
\text { Pseudodistoma } \\
\text { antinboja }\end{array}$ & $\begin{array}{l}\text { S. aureus, S. epidermidis, } \\
\text { Kocuria rhizophila and } \\
\text { B. subtilis, } \\
\text { methicillin-sensitive } \\
\text { S. aureus (MSSA), MRSA } \\
\text { inhibition }\end{array}$ & $\begin{array}{c}0.13-12.5 \mu \mathrm{g} / \mathrm{mL} \\
\text { (MIC) }\end{array}$ & {$[53]$} \\
\hline Antibacterial & $\begin{array}{c}\text { Cytosporones B } \\
(\mathbf{3 3}), \text { E (34) }\end{array}$ & $\begin{array}{c}\text { Fungus: Leucostoma } \\
\text { persoonii }\end{array}$ & $\begin{array}{c}\text { S. aureus USA100, } \\
\text { MRSA, MSSA inhibition }\end{array}$ & $72-78 \mu \mathrm{M}$ (MIC) & {$[54]$} \\
\hline Antibacterial & $\begin{array}{l}\text { Anthracimycin } \\
\text { (35) }\end{array}$ & $\begin{array}{c}\text { Bacterium: } \\
\text { Streptomyces sp. }\end{array}$ & $\begin{array}{l}\text { B. anthracis, } \\
\text { Enterococcus facecalis, } \\
\text { Streptococcus pneumonia, } \\
\text { S. aureus, MSSA, MRSA, } \\
\text { vancomycin-resistant } \\
\text { S. aureus inhibition }\end{array}$ & $\begin{array}{c}0.03125-0.25 \mu \mathrm{g} / \mathrm{mL} \\
\text { (MIC) }\end{array}$ & {$[55]$} \\
\hline Antifungal & Halocidin (36) & $\begin{array}{c}\text { Ascidian: Halocynthia } \\
\text { aurantium }\end{array}$ & $\begin{array}{c}\text { Candida albicans } \\
\text { inhibition }\end{array}$ & $1-4 \mu \mathrm{g} / \mathrm{mL}(\mathrm{MIC})$ & {$[56]$} \\
\hline Antifungal & $\begin{array}{c}\text { Callipeltine J (37), } \\
\text { K (38) }\end{array}$ & Sponge: Latrunculia sp. & C. albicans inhibition & $1 \mu \mathrm{M}(\mathrm{MIC})$ & [57] \\
\hline Antifungal & Pedein A (39) & $\begin{array}{l}\text { Bacterium: } \\
\text { Chondromyces } \\
\text { pediculatus }\end{array}$ & $\begin{array}{c}\text { Rhizopus glutinis, } \\
\text { Saccharomyces cerevisae, } \\
\text { C. albicans inhibition }\end{array}$ & $\begin{array}{c}0.6-1.6 \mu \mathrm{g} / \mathrm{mL} \\
\text { (MIC) }\end{array}$ & [58] \\
\hline Antifungal & $\begin{array}{l}\text { Theuellamide F } \\
\qquad(\mathbf{4 0}), G(\mathbf{4 1})\end{array}$ & Sponge: Theonella sp. & C. albicans inhibition & $2-4.49 \mu \mathrm{M}\left(\mathrm{IC}_{50}\right)$ & {$[59,60]$} \\
\hline
\end{tabular}


Table 1. Cont.

\begin{tabular}{|c|c|c|c|c|c|}
\hline Antifungal & $\begin{array}{c}\text { Theopapuamide B } \\
\text { (42), C (43) }\end{array}$ & $\begin{array}{c}\text { Sponge: } \\
\text { Siliquariaspongia } \\
\text { mirabilis }\end{array}$ & C. albicans inhibition & $\begin{array}{l}1-5 \mu \mathrm{g} / \mathrm{disk} \\
(\text { disk })\end{array}$ & {$[61]$} \\
\hline Antifungal & C(15)-surfactin (44) & $\begin{array}{c}\text { Bacterium: } \\
\text { B. amyloliquefaciens }\end{array}$ & C. albicans inhibition & $\begin{array}{c}0.004 \mu \mathrm{g} / \mathrm{mL} \\
(\mathrm{MIC}) \\
\end{array}$ & {$[62]$} \\
\hline Antifungal & $\begin{array}{c}\text { Anti-CA } \\
\text { cyclic lipopeptide } \\
\text { (45) }\end{array}$ & $\begin{array}{l}\text { Bacterium: } \\
\text { B. amyloliquefaciens }\end{array}$ & $\begin{array}{c}\text { C. tropicalis, Metschnikowia } \\
\text { bicuspidata, Sacchromyces } \\
\text { cerevisiae, Yarrowia } \\
\text { lipolytica inhibition } \\
\end{array}$ & $7.0 \mu \mathrm{g} / \mathrm{mL}$ (MIC) & [63] \\
\hline Antifungal & $\begin{array}{l}\text { Maribasins A (46), } \\
\text { B (47) }\end{array}$ & Bacteriun: $B$. marinus & $\begin{array}{l}\text { Alternaria solani, Fusarium } \\
\text { oxysporum, } \\
\text { Verticillium alboatrum, } \\
\text { F. graminearum, Sclerotium } \\
\text { sp., Penicillium sp., } \\
\text { Rhizoctonia solani, } \\
\text { Colletotrichum } \text { sp. inhibition }\end{array}$ & $\begin{array}{c}25-200 \mu \mathrm{g} / \mathrm{mL} \\
\text { (MIC) }\end{array}$ & [64] \\
\hline Antifungal & Mojavensin A (48) & $\begin{array}{l}\text { Bacterium: } \\
\text { B. mojavensis }\end{array}$ & $\begin{array}{c}\text { Phytopathogenic fungi } \\
\text { inhibition }\end{array}$ & ND & {$[65]$} \\
\hline Antifungal & Kahalalide F (49) & $\begin{array}{l}\text { Mollusk: Elysia } \\
\text { rufescens }\end{array}$ & $\begin{array}{c}\text { C. albicans, } \\
\text { C. neoformans, Aspergillus } \\
\text { fumigatus inhibition }\end{array}$ & $\begin{array}{c}1.53-3.21 \mu \mathrm{M} \\
\left(\mathrm{IC}_{50}\right)\end{array}$ & {$[66]$} \\
\hline Antifungal & $\begin{array}{l}\text { Miraenamide A } \\
(\mathbf{5 0}), \mathrm{B}(\mathbf{5 1})\end{array}$ & $\begin{array}{l}\text { Bacterium: } \\
\text { Paraliomyxa } \\
\text { miuraensis }\end{array}$ & $\begin{array}{l}\text { A. niger, Phytophthora } \\
\text { capsici, Rhizopus oryzae, } \\
\text { C. rugosa, inhibition }\end{array}$ & $\begin{array}{l}0.4-25 \mu \mathrm{M} \\
\quad(\mathrm{MIC})\end{array}$ & {$[67,68]$} \\
\hline Antifungal & $\begin{array}{c}\text { Callyaerin A (52), } \\
\text { E (53) }\end{array}$ & $\begin{array}{c}\text { Sponge: Callyspongia } \\
\text { aerizusa }\end{array}$ & C. albicans inhibition & $\begin{array}{c}5-10 \mu \mathrm{g} / \text { disk } \\
(\text { disk })\end{array}$ & [69] \\
\hline Antimalarial & Dragomabin (54) & $\begin{array}{l}\text { Bacterium: Lyngbya } \\
\text { majuscula }\end{array}$ & $\begin{array}{c}\text { Plasmodium falciparum W2 } \\
\text { strain inhibition }\end{array}$ & $6.0 \mu \mathrm{M}\left(\mathrm{IC}_{50}\right)$ & {$[70]$} \\
\hline Antimalarial & $\begin{array}{l}\text { Venturamid A (55), } \\
\text { B (56) }\end{array}$ & $\begin{array}{c}\text { Bacterium: } \\
\text { Oscillatoria sp. }\end{array}$ & $\begin{array}{c}\text { Plasmodium falciparum } \mathrm{W} 2 \\
\text { strain inhibition }\end{array}$ & $\begin{array}{c}5.6-8.2 \mu \mathrm{M} \\
\left(\mathrm{IC}_{50}\right) \\
\end{array}$ & [71] \\
\hline Antimalarial & $\begin{array}{l}\text { Aerucyamide A-D } \\
\qquad(\mathbf{5 7 - 6 0 )}\end{array}$ & $\begin{array}{l}\text { Bacteriun: } \\
\text { Microcystis } \\
\text { aeruginosa } \\
\end{array}$ & $\begin{array}{l}\text { Plasmodium falciparum K1 } \\
\text { strain inhibition }\end{array}$ & $0.7 \mu \mathrm{M}\left(\mathrm{IC}_{50}\right)$ & {$[72,73]$} \\
\hline Antimalarial & Gallinamide A (61) & $\begin{array}{c}\text { Bacterium: } \\
\text { Schizothrix sp. }\end{array}$ & $\begin{array}{c}\text { Plasmodium falciparum } \mathrm{W} 2 \\
\text { strain inhibition }\end{array}$ & $8.4 \mu \mathrm{M}\left(\mathrm{IC}_{50}\right)$ & [74] \\
\hline Antimalarial & $\begin{array}{l}\text { Lagunamide A }(\mathbf{6 2}), \\
\text { B (63) }\end{array}$ & $\begin{array}{l}\text { Bacterium: Lyngbya } \\
\text { majuscula }\end{array}$ & $\begin{array}{l}\text { Plasmodium falciparum } \\
\text { NF54 strain inhibition }\end{array}$ & $\begin{array}{c}0.19-0.91 \mu \mathrm{M} \\
\left(\mathrm{IC}_{50}\right) \\
\end{array}$ & [75] \\
\hline Antimalarial & $\begin{array}{c}\text { Albopunctatone } \\
(\mathbf{6 4}) \\
\end{array}$ & $\begin{array}{c}\text { Ascidian: Didemnum } \\
\text { albopunctatum }\end{array}$ & $\begin{array}{c}\text { Plasmodium falciparum Dd2, } \\
\text { 3d7 strain inhibition }\end{array}$ & $\begin{array}{c}4.4-5.3 \mu \mathrm{M} \\
\left(\mathrm{IC}_{50}\right) \\
\end{array}$ & [76] \\
\hline Antiprotozoal & $\begin{array}{l}\text { Viridamide A (65), } \\
\text { B (66) }\end{array}$ & $\begin{array}{l}\text { Bacterium: } \\
\text { Oscillatoria } \\
\text { nigro-viridis }\end{array}$ & $\begin{array}{c}\text { Leishmania mexicana, } \\
\text { Trypanosoma cruzi inhibition }\end{array}$ & $\begin{array}{c}1.1-1.5 \mu \mathrm{M} \\
\quad\left(\mathrm{IC}_{50}\right)\end{array}$ & [77] \\
\hline Antiprotozoal & $\begin{array}{l}\text { Almiramides B } \\
\qquad(67), C(68)\end{array}$ & $\begin{array}{c}\text { Bacterium: } \\
\text { Lyngbya majuscula }\end{array}$ & $\begin{array}{l}\text { Leishmania donovani } \\
\text { inhibition }\end{array}$ & $\begin{array}{c}1.9-2.4 \mu \mathrm{M} \\
\left(\mathrm{IC}_{50}\right)\end{array}$ & [78] \\
\hline
\end{tabular}


Table 1. Cont.

\begin{tabular}{|c|c|c|c|c|c|}
\hline Antiprotozoal & Valinomycin (69) & $\begin{array}{c}\text { Bacterium: } \\
\text { Streptomyces sp. }\end{array}$ & $\begin{array}{c}\text { Leishmania major \& } \\
\text { Trypanosoma brucei brucei } \\
\text { inhibition }\end{array}$ & $\begin{array}{c}0.0032-0.11 \mu \mathrm{M} \\
\left(\mathrm{IC}_{50}\right)\end{array}$ & [79] \\
\hline Antiprotozoal & $\begin{array}{c}\text { Diketopiperazines } \\
(\mathbf{7 0}-\mathbf{8 1}) \\
\end{array}$ & $\begin{array}{l}\text { Fungus: A. fumigatus, } \\
\text { Nectria inventa }\end{array}$ & Trypanosoma brucei & $\begin{array}{c}0.002-40 \mu \mathrm{M} \\
\left(\mathrm{IC}_{50}\right) \\
\end{array}$ & {$[80]$} \\
\hline Antituberculosis & $\begin{array}{l}\text { Trichoderin A }(\mathbf{8 2}), \\
\text { A1 (83), B (84) }\end{array}$ & $\begin{array}{c}\text { Fungus: } \\
\text { Trichoderma sp. }\end{array}$ & $\begin{array}{c}\text { Mycobacterium tuberculosis } \\
\text { inhibition }\end{array}$ & $\begin{array}{c}0.02-2 \mu \mathrm{g} / \mathrm{mL} \\
(\mathrm{MIC})\end{array}$ & {$[81]$} \\
\hline Antiviral & $\begin{array}{c}\text { Mirabamides A } \\
\text { (85), C (86), D (87), } \\
\text { E-H (88-91) }\end{array}$ & $\begin{array}{c}\text { Sponge: } \\
\text { Siliquariaspongia } \\
\text { mirabilis } \\
\end{array}$ & Anti-HIV-1 & $\begin{array}{c}0.041-3.9 \mu \mathrm{M} \\
\left(\mathrm{IC}_{50}\right)\end{array}$ & {$[82]$} \\
\hline Antiviral & Mollamides B (92) & $\begin{array}{c}\text { Tunicate: } \\
\text { Didemmum molle }\end{array}$ & Anti-HIV & $48.7 \mu \mathrm{M}\left(\mathrm{EC}_{50}\right)$ & [83] \\
\hline Antiviral & Papuamide A (93) & $\begin{array}{c}\text { Tunicate: } \\
\text { Didemmum molle }\end{array}$ & Anti-HIV & $71 \mathrm{nM}\left(\mathrm{EC}_{50}\right)$ & [84] \\
\hline Antiviral & $\begin{array}{l}\text { Celebesides A }(\mathbf{9 4}) \\
\qquad \text { C (95) }\end{array}$ & $\begin{array}{c}\text { Sponge: } \\
\text { Siliquariaspongia } \\
\text { mirabilis } \\
\end{array}$ & Anti-HIV-1 & $1.9 \mu \mathrm{g} / \mathrm{mL}\left(\mathrm{IC}_{50}\right)$ & {$[61]$} \\
\hline Antiviral & $\begin{array}{c}\text { Theopapuamide A } \\
\text { (96), D (97) }\end{array}$ & $\begin{array}{c}\text { Sponge: } \\
\text { Theonella swinhoei }\end{array}$ & Anti-HIV-1 & $0.5 \mu \mathrm{M}\left(\mathrm{IC}_{50}\right)$ & {$[61,85]$} \\
\hline Antiviral & $\begin{array}{c}\text { Asperterrestide A } \\
\mathbf{( 9 8 )} \\
\end{array}$ & $\begin{array}{c}\text { Fungus: Aspergillus } \\
\text { terreus }\end{array}$ & Anti-HIN1, Anti-H3N2 & $\begin{array}{c}0.41-20.2 \mu \mathrm{M} \\
\left(\mathrm{IC}_{50}\right) \\
\end{array}$ & [86] \\
\hline Antiviral & $\begin{array}{l}\text { Homophymine A-E } \\
\qquad \begin{array}{l}(\mathbf{9 9}-\mathbf{1 0 3}) \\
\text { A1-E1 (104-108) }\end{array}\end{array}$ & $\begin{array}{c}\text { Sponge: } \\
\text { Homophymia sp. }\end{array}$ & Anti-HIV-1 & $75 \mathrm{nM}\left(\mathrm{IC}_{50}\right)$ & {$[87,88]$} \\
\hline Antiviral & $\begin{array}{l}\text { Koshikmaide B } \\
\qquad \begin{array}{c}\mathbf{1 0 9}), \mathrm{F}-\mathrm{H} \\
(\mathbf{1 1 0}-\mathbf{1 1 2})\end{array}\end{array}$ & Sponge: Theonella sp. & Anti-HIV-1 & $2.3 \mu \mathrm{M}\left(\mathrm{IC}_{50}\right)$ & {$[89,90]$} \\
\hline
\end{tabular}

\subsection{Antibacterial Activity}

Several different organisms use antimicrobial peptides, typically 20-40 amino acids in length, for defense against infection. Most are capable of rapidly killing a wide range of microbes. Large antimicrobial proteins (>100 amino acids), are often lytic, nutrient-binding proteins or target specific microbial peptides by disrupting the structure or function of microbial cell membranes. A multitude of antimicrobial proteins have been found in the epithelial layers, phagocytes, and body fluids of multicellular animals, including humans. In addition to their role as endogenous antibiotics, antimicrobial peptides (AMP) contribute to inflammation, wound repair, and regulation of the adaptive immune system [91]. As part of ongoing global efforts to discover novel antimicrobials to treat infections caused by resistant pathogenic organisms, 35 studies have since 2006 reported novel antibacterial peptides isolated from marine sources such as bacteria, sponges, mud crabs, ascidin, spider crabs, jellyfish, and fish. 


\subsubsection{Aurelin}

Ovchinnikova et al. reported in the purification of a 40-residue AMP from the mesoglea of a scyphoid jellyfish, Aurelia aurita, Linnaeus, 1758 [31] (Figure 1). The peptide was named aurelin (1), and exhibited activity against gram-positive and gram-negative bacteria. Minimum inhibitory concentrations (MIC) were defined under low salt conditions (10 mM sodium phosphate buffer, $\mathrm{pH} 7.4$ ). Aurelin inhibited the growth of microorganisms (MICs: $22.64 \mu \mathrm{g} / \mathrm{mL}$ against Listeria monocytogenes and $7.66 \mu \mathrm{g} / \mathrm{mL}$ against Escherichia coli). Interestingly, aurelin showed no sequence homology to any previously identified AMP, but displayed partial similarity to both defensins and K-channel-blocking toxins of sea anemones [31].

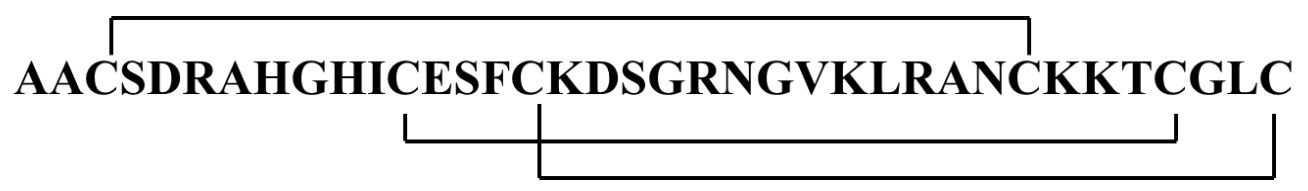

Figure 1. Amino acid sequence of aurelin (1). Aurelin was isolated from the mesoglea of a scyphoid jellyfish, Aurelia aurita [31]. Aurelin has six cysteine residues, forming three disulfide bonds.

\subsubsection{Arenicin-1}

Lee et al. reported that the 21-residue peptide arenicin-1 (2), isolated from the marine polychaete Arenicola marina, exhibited significant antibacterial activity against Pseudomonas aeruginosa and Staphylococcus aureus (MIC $=2 \mu \mathrm{g} / \mathrm{mL}$ ) [32]. Arenicin-1 contained one disulfide bond (Cys3-Cys20), and formed a typical $\beta$-hairpin structure [33] (Figure 2). Arenicin-1 can disrupt the cell membrane through the formation of highly oligomerized states, which cause pore formation [92]. These results emphasize the inherent difficulty in predicting the antimicrobial potential and the mode of action of a rather simple scaffold. Furthermore, arenicin-1 induced the release of calcein from PE/PG liposomes, thus suggesting that the bacterial cell membrane is the main molecular target of the peptide [33].

\section{RWCVYAYVRVRGVLVRYRRCW}

Figure 2. Amino acid sequence of arenicin-1 (2). Arenicin was isolated from the marine polychaete Arenicola marina [32]. Arenicin-1 contained one disulfide bond and formed a typical $\beta$-hairpin structure.

\subsubsection{Tauramamide}

Tauramamide (3) is produced by cultures of the marine bacterial isolate Brevibacillus laterosporus PNG276, obtained from Papua New Guinea [34]. Tauramamide is a new lipopeptide antibiotic that contains two D-amino acids and is acylated at the $N$-terminus, two hallmarks of a non-ribosomal peptide synthase biosynthetic origin. Tauramamide showed potent $(\mathrm{MIC}=0.1 \mu \mathrm{g} / \mathrm{mL}$ ) and relatively selective inhibition of the gram-positive human pathogen Enterococcus sp. Moreover, tauramamide showed weak 
activity against Methicillin resistant S. aureus (MRSA; MIC $=200 \mu \mathrm{g} / \mathrm{mL}$ ), although it was not appreciably active against Candida albicans $(\mathrm{MIC}=50 \mu \mathrm{g} / \mathrm{mL})$.

\subsubsection{Hepcidins}

Hepcidins (4) are cysteine-rich peptides isolated from tilapia (Oreochromis mossambicus), with MICs (50-100 $\mu \mathrm{g} / \mathrm{mL})$ against L. monocytogenes, S. aureus, and Enterococcus faecium [35]. Hepcidins are antimicrobial peptides that play important roles in resisting pathogenic infection. Through hybridization of a phage library, the cDNA sequences of three hepcidin-like antimicrobial peptides (named TH1-5, TH2-2, and TH2-3) were identified in tilapia (Figure 3). The predicted molecular weights of TH1-5, TH2-2, and TH2-3 are 9.5, 9.4, and $9.8 \mathrm{kDa}$, respectively. Fish hepcidins are active against a wide variety of bacteria, both gram-positive and -negative in the low $\mu \mathrm{M}$ range, including potent activity against a large number of fish pathogens. In contrast, their quantified activity against fungi appears to be rather low [35].

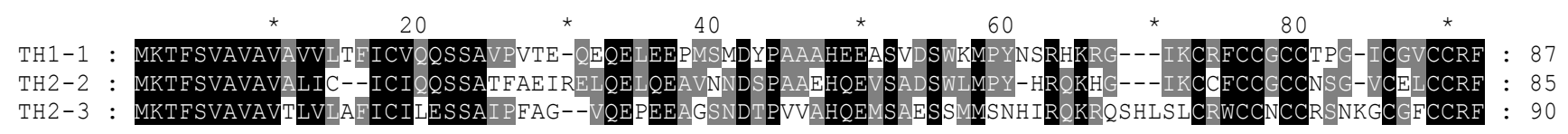

Figure 3. Sequence alignment of three tilapia hepcidins (TH1-5, TH2-2, and TH2-3). Three hepcidins (4) were isolated from tilapia (Oreochromis mossambicus) [35]. Identical or similar amino acid residues are in same colors. Gaps are inserted to obtain maximum homology.

\subsubsection{Scygonadin}

Scygonadin (5) is an anionic antimicrobial peptide recently identified from the seminal plasma of Scylla serrata. [36,37]. This molecule (Figure 4), which showed no homology to any other protein in databanks, was able to inhibit Micrococcus luteus growth [93]. Scygonadin showed activity against E. coli $(\mathrm{MIC}=25-50 \mu \mathrm{g} / \mathrm{mL})$, P. aeruginosa $(\mathrm{MIC}=12.5-25 \mu \mathrm{g} / \mathrm{mL})$, S. aureus $(\mathrm{MIC}=50-100 \mu \mathrm{g} / \mathrm{mL})$ and Streptococcus pyogenes $(\mathrm{MIC}=25-50 \mu \mathrm{g} / \mathrm{mL}$ ). To gain more detailed information about its antimicrobial activity, the mature scygonadin peptide was expressed in E. coli to obtain a large quantity of the biologically active product. An approximately 43-kDa fusion protein, CKS-scygonadin, was obtained, and was highly stable and active [37].

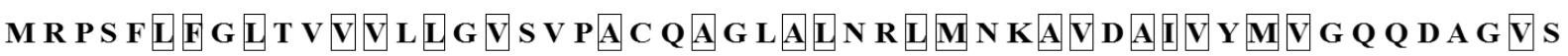

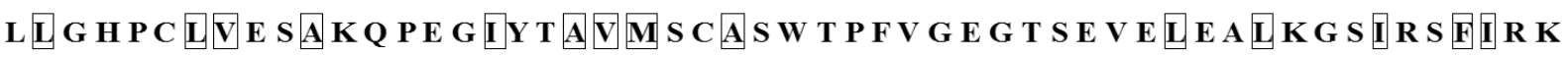

A S D Y QLLS KE D LEDWLASY

Figure 4. Amino acid sequence of scygonadin (5). Scygonadin was isolated from the seminal plasma of the mud crab, Scylla serrate [36,37]. Scygonadin contained $\alpha$-helices and had 39 residues on the same hydrophobic surface. Scygonadin may interact with cell membranes. 


\subsubsection{Tunichromes}

Tunichromes (6) are small peptides containing one or more dehydrodopa-derived units that have been identified in several species of tunicates. Incubation of tunichromes isolated from Ascidia nigra hemocytes under oxidative conditions possess inherent crosslinking properties in vitro [38]. Three tunichromes have also been isolated from the blood cells of Ascidia nigra (An-1, An-2, An-3) [39]. Tunichromes show potent $(\mathrm{MICs}=0.1 \mu \mathrm{g} / \mathrm{mL}$ ) and relatively selective activity against the gram-positive human pathogen Enterococcus sp. [38].

\subsubsection{Bacillistatins 1 and 2}

Two new cyclodepsipeptides, designated bacillistatins 1 (7) and 2 (8), have been isolated from cultures of a sample of Bacillus silvestris that was obtained from a Pacific Ocean (southern Chile) crab. Each 12-unit cyclodepsipeptide strongly inhibited growth in a human cancer cell line panel, with a 50\% growth inhibition values (GI50s) of $10^{-4}-10^{-5} \mu \mathrm{g} / \mathrm{mL}$. Further, each compound was active against antibiotic-resistant Streptococcus pneumoniae [40].

\subsubsection{Thiopeptide TP-1161}

The thiopeptide TP-1161 (9) was identified in a Norwegian marine sediment-derived gram-positive bacterium, Nocardiopsis sp. [41]. The in vitro antibacterial activity of TP-1161 was assessed against a panel of gram-negative and gram-positive bacteria, mostly representing clinical isolates. All of the gram-negative strains tested (six E. coli, two Klebsiella pneumoniae, one Salmonella enterica serovar Choleraesuis, and four $P$. aeruginosa) were not susceptible to TP-1161. However, the MICs against gram-positive strains ranged from 0.25 to $4 \mu \mathrm{g} / \mathrm{mL}$, which was comparable to or lower than those of the reference antibiotic vancomycin. TP-1161 also inhibited the growth of vancomycin-resistant bacterial strains, including Enterococcus faecalis 560 and Enterococcus faecium 569, with an MIC of $1 \mu \mathrm{g} / \mathrm{mL}$.

\subsubsection{Centrocins}

Two novel AMPs, named centrocin $1(\mathbf{1 0}, 4.5 \mathrm{kDa})$ and $2(\mathbf{1 1}, 4.4 \mathrm{kDa})$, were purified from coelomocyte extracts of the green sea urchin, Strongylocentrotus droebachiensis (Figure 5). The native peptides are cationic and show potent activity against gram-positive (Corynebacterium glutamicum, S. aureus; $\mathrm{IC}_{50}=1.3-5 \mu \mathrm{M}$ ) and gram-negative (Listonella anguillarum, E. coli; $\mathrm{IC}_{50}=1.3-2.5 \mu \mathrm{M}$ ) bacteria. The centrocins have an intramolecular heterodimeric structure containing a heavy chain (30 amino acids) and a light chain (12 amino acids) [42].

\subsubsection{Halocyntin and Papillosin}

Halocyntin (12) and papillosin (13) are two new peptides (MIC $=0.75-25 \mu \mathrm{M}$ ) isolated from hemocytes of the Mediterranean ascidian Halocynthia papillosa [43]. Papillosin (GFWKKVGSAAWG GVKAAAKGAAVGGLNALAKHIQ, 34 amino acids residues) is longer than halocyntin (FWGHIWNAVKRVGANALHGAVTGALS, 26 amino acids residues), and also has a higher net charge (Figure 6). 


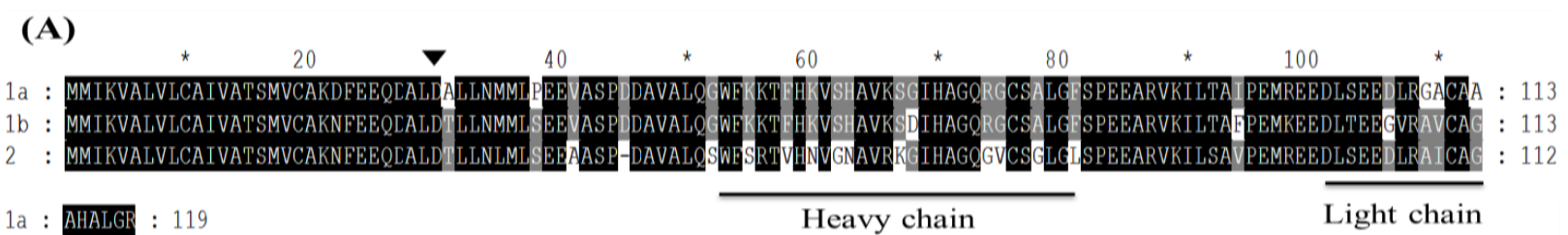

(B)

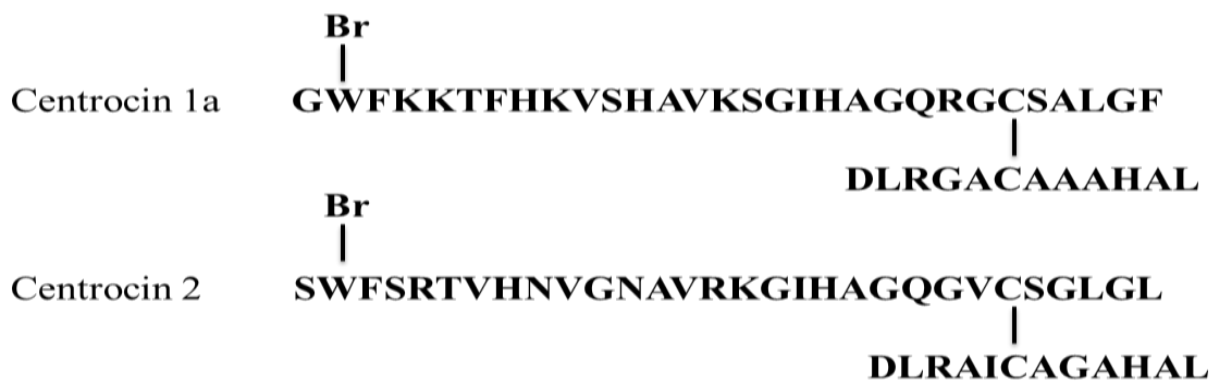

Figure 5. The alignment of centrocin 1 (10) and 2 (11) from Strongylocentrotus droebachiensis (A) and the proposed structure of centrocins 1a and 2 (B) [42]. The predicted cleavage site between the signal peptides and the prosequences are shown by a solid triangle $(\boldsymbol{\nabla})$. Identical residues are shaded in black, whereas similar residues are shaded in gray. The boxes indicate the heavy chain and the light chain regions. In the proposed structure of centrocin, the heavy chain and the light chain are connected by disulfide bridges. The brominated tryptophan in position 2 of the active centrocin is labeled with a $\mathrm{Br}$ on the top.
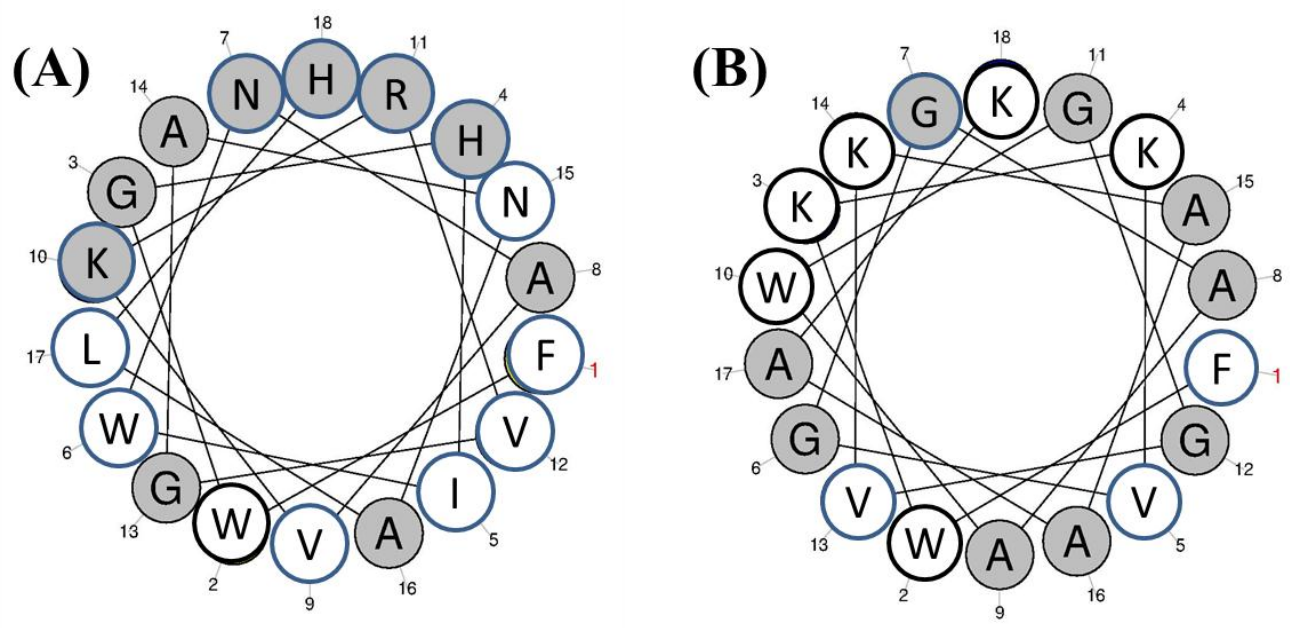

Figure 6. Helical wheel diagrams of halocyntin (A, 12) and residues 2-19 of papillosin $(\mathbf{B}, \mathbf{1 3})$ are shown, with the polar residues shaded gray. The clearly evident clustering of polar and apolar residues imparts amphipathicity [43].

Halocyntin (12) had marked activity against gram-positive strains, particularly Micrococcus luteus, Bacillus megaterium, and Aerococcus viridans $(0.39 \mu \mathrm{M}<$ minimum bactericidal concentration [MBC] $<1.56 \mu \mathrm{M})$. It also showed activity against $S$. aureus and Entrococcus faecalis $(1.56 \mu \mathrm{M}<\mathrm{MBC}<$ $3.13 \mu \mathrm{M})$. Halocyntin activity against gram-negative bacteria was significantly lower, with MBCs between 6.25 and $50 \mu \mathrm{M}$, with the exception of Klebsiella pneumoniae that had MBC betwwen $1.56 \mu \mathrm{M}$ and $3.13 \mu \mathrm{M}[43]$. 
Papillosin (13) showed important antibacterial activity against both gram-positive and gram-negative bacteria. Growth inhibition of gram-positive bacteria was particularly strong for M. luteus, B. megaterium, and Aerococcus viridans $(0.05 \mu \mathrm{M}<\mathrm{MBC}<0.39 \mu \mathrm{M})$, whereas $S$. aureus growth was less affected $(1.56 \mu \mathrm{M}<\mathrm{MBC}<3.13 \mu \mathrm{M})$. In contrast to halocyntin, papillosin also has strong activity against gram-negative bacteria $(0.39 \mu \mathrm{M}<\mathrm{MBC}<1.56 \mu \mathrm{M})$, with the exception of $P$. aeruginosa $(3.13 \mu \mathrm{M}<\mathrm{MBC}<6.25 \mu \mathrm{M})[43]$.

Papillosin possesses potent activity against gram-positive and gram-negative bacteria. Halocyntin is active against all the gram-positive bacteria tested, but its activity against gram-negative bacteria is effective but much less potent. In addition, for all strains tested, papillosin present a higher antibacterial activity than halocyntin.

\subsubsection{Hyastatin}

Hyastatin (14) is a glycine-rich multi-domain peptide from hemocytes of the Norwegian spider crab Hyas araneus [44]. It consists of three distinctly different domains: an $N$-terminal region enriched in Gly residues, a short Pro/Arg-rich region, and a $C$-terminal region containing six Cys residues with a Cys pattern resembling the one found in penaeidins (Figure 7). The hyastatin transcript is constitutively expressed, and is primarily found in hemocytes. Hyastatin was purified in its native form Hyas araneus hemocytes and its antimicrobial potential was estimated against selected bacteria and fungi. The MIC value was defined as $50 \%$ growth inhibition compared to the growth control, and the highest concentration tested was $50 \mu \mathrm{M}$. Hyastatin had moderate activity against $E$. coli $(\mathrm{MIC}=12.5 \mu \mathrm{M})$, but showed no activity against $P$. aeruginosa. The activity against gram-positive bacteria was either very strong or absent, with MIC values of $0.4 \mu \mathrm{M}$ and $>50 \mu \mathrm{M}$ against Corynebacterium glutamicum and S. aureus, respectively [44].

MRVLLILVSLAALAHAESFLKSKTGYQGVQTLPGFIGGSQ

Signal Sequence

PHLGGGIGGGRPFISQPNLGGGIGGGIGGGKPFIPQPNLG

Gly-rich region

\section{GQIGSTRPFPRPQYGDYGSRNSCNRQCPSTYGGRGICCRR}

Pro-/Arg- containing region

\section{WGSCCPTNYKG}

Cys- containing region

Figure 7. Amino acid sequences and overall peptide structure of hyastatin (14), isolated from the hemocytes of Hyas araneus [44]. The different regions are distinguished with boxes and given a designation below. The sequence of hyastatin has been submitted to the NCBI GenBank database with the accession number FJ764995. 


\subsubsection{Indigoidine}

A blue pigment is associated with Phaeobacter sp. Y4I-mediated inhibition of Vibrio fischeri [45]. This pigment, referred to as indigoidine (15), is produced by the condensation of two glutamine residues via a nonribosomal peptide synthase-based biosynthetic pathway. The indigoidine biosynthetic genes are $i g i B$, which codes for a 6-phosphogluconate dehydrogenase, igiC, for a glutamate racemase, and igiD for indigoidine synthase [94].

\subsubsection{Unnarmicins}

Unnarmicins are depsipeptides isolated from the fermentation broth of a marine bacterium Photobacterium sp. MBIC06485. Unnarmicins A (16) and C (17) contain two Leu, and two Phe. The difference between the two peptides was due to replacement of the 3-hydroxyoctanoyl moiety in A (16) with the 3-hydroxyhexanoyl group in C (17) [46]. These compounds exert antibacterial activity against only one species in the Pseudovibrio genus, a common $\alpha$-Proteobacteria genera in the marine environment [46]. The antibacterial activity of unnarmicins against two gram-positive bacteria (Firmicutes) and seven halophilic gram-negative bacteria belonging to Bacteroidetes, Alphaproteobacteria, and Gammaproteobacteria was evaluated by a plate diffusion assay [46].

\subsubsection{Ngercheumicins}

Depsipeptides from Photobacterium strains that are active against the non-pathogenic Pseudovibrio denitrificans were patented in 2007, and called ngercheumicins [47]. To date, five depsipeptides, ngercheumicins A-E, have been purified and characterized. Ngercheumicins A (18) and B (19) have a depsipeptide macrocycle containing one Phe and two Leu residues with different fatty acid tails. Ngercheumicins C (20) and D (21) have a macrocycle composed of three Leu, two Thr, and one Ser, with no fatty acid tails [47]. Although these compounds only target bacteria for which no pathologies have been described to date, ngercheumicins can be added to culture media to enhance the proliferation of slow-growing marine bacteria.

\subsubsection{Solonamides}

Marine Photobacterium produce cyclodepsipeptides, called solonamides. Various depsipeptides have been identified in this genus, suggesting that this type of compound may be a common feature in Photobacterium [48]. No antibacterial activity has been observed for solonamides A (22) and B (23), although the activity has only been assessed against Vibrio anguillarum and S. aureus. Nevertheless, solonamide B (23) has been reported to reduce the expression of MRSA hla and rnaIII, two genes involved in strain virulence, controlled by an agr-dependent quorum sensing system. The structural similarity of the solonamides and the auto-inducing peptides involved in $S$. aureus quorum sensing suggests that solonamides may be competitive inhibitors of the agr system [48]. The reduced activity of solonamide A compared with solonamide B indicates that the overall hydrophobicity of the depsipeptides, due to the fatty acid chain, may have an important impact on inhibiting the expression of virulence genes in S. aureus. 


\subsubsection{Cyclo-Peptides}

A Pseudoalteromonas sp. associated with the sponge Halisarca ectofibrosa has been isolated for its ability to inhibit $S$. aureus, M. luteus, B. subtilis, E. coli and V. anguillarum [49]. The resulting fermentation broth contains four cyclo-peptides (24): cyclo-(Phe-Pro-Leu-Pro), cyclo-(Leu-Pro)2, cyclo-(Phe-Leu)2, and cyclo-(Leu-Ile) 2 [49].

Although the fermentation broth extracted with methanol inhibits several target bacteria, no inhibitory activity is observed when cyclo-peptides are used alone. However, employing a solid phase synthesis method, the cyclo-(Phe-Pro-Leu-Pro) has been shown to exert a significant inhibitory activity against gram-negative bacteria, including $P$. aeruginosa and Klebsiella oxytoca [95]. The biosynthetic pathways involved in the synthesis of cyclo-peptides have not been investigated. The structural analogy with other tetrapeptides, however, suggests that NRPS modules are at the origin of this peptide, as in Streptomyces [96].

\subsubsection{Ariakemicins}

Ariakemicins A (25) and B (26) are unusual, linear, hybrid, polyketide-nonribosomal peptide antibiotics from a marine gliding bacterium of the genus Rapidithrix [50]. The ariakemicins were composed of threonine, two $\Omega$-amino-( $\Omega$-3)-methyl carboxylic acids with diene or triene units, and $\delta$-isovanilloylbutyric acid. The ariakemicins were tested against a panel of microbial strains consisting of three gram-positive bacteria (Brevibacterium sp., S. aureus, and B. subtilis: $83 \mu \mathrm{g} / \mathrm{mL}$ ), four gram-negative bacteria (Cytophaga marinoflava, Pseudovibrio sp., E. coli, and P. aeruginosa: $83 \mu \mathrm{g} / \mathrm{mL}$ ), and a yeast (C. albicans). The antibiotic mixture selectively inhibited the growth of gram-positive bacteria, among which $S$. aureus $(0.46 \mu \mathrm{g} / \mathrm{mL})$ was the most affected. The antibiotics had slight cytotoxicity against A549 human lung cancer cells and BHK baby hamster kidney cells with $\mathrm{IC}_{50}$ values of 25 and $15 \mu \mathrm{g} / \mathrm{mL}$, respectively [50].

\subsubsection{Damicornin}

Vidal-Dupiol et al. reported that the 4492.35 Da peptide amicornin (27) from a scleractinian coral of Pocillopora damicornis [51]. Its precursor has a segmented organization comprising a signal peptide, an acidic proregion, and the $C$-terminal AMP. The 40-residue AMP is cationic, $C$-terminally amidated, and characterized by the presence of six cysteine molecules joined by three intramolecular disulfide bridges. Its cysteine array is common to another AMP and toxins from cnidarians [51] (Figure 8). Damicornin had antimicrobial activity against Gram-positive bacteria (M. luteus, B. megaterium, S. aureus, Brevibacterium stationis and Microbacterium maritypicum; $\mathrm{MIC}=1.25-20 \mu \mathrm{M}$ ) and the filamentous fungus Fusarium oxysporum (MIC $=20 \mu \mathrm{M}$ ) but had little activity against Gram-negative bacteria except $E$. coli $(\mathrm{MIC}=20 \mu \mathrm{M})$. In addition, the gene for expression of damicornin is repressed concomitantly with the invasion of host ectodermal cells by the coral pathogen Vibrio coralliilyticus [51]. 


\section{YSCGCRG}

Figure 8. Deduced amino acid sequences of preprodamicornin. The arrow identifies the cleavage site of the signal peptide. The dibasic cleavage site between the acidic $N$-terminal proregion and the cationic $C$-terminal region is outlined in black. The damicornin active peptide is underlined in black. The cysteine residues and glycine amidation signal are shown in bold [51].

\subsubsection{Clavanins}

Clavanins (28) are antimicrobial peptides isolated from the marine tunicate Styela clava, showing 23 amino acid residues in length, cationic properties, and also high bactericidal activity [52]. In spite of clear benefits from the use of peptides, currently $95 \%$ of peptide properties have limited pharmaceutical applicability, such as low solubility and short half-life in the circulatory system. Saude et al. was reported that nanostructured clavanin A form shows improved antimicrobial activity and has the potential to be used to treat polymicrobial infections [52]. In vitro bioassays showed that the nanostructured clavanin was partially able to control development of S. aureus, Klebsiella pneumoniae and $P$. aeruginosa. In vivo sepsis bioassays were performed using C57BL6 mice strain inoculated with a polymicrobial suspension. Assays led to $100 \%$ survival rate under sub-lethal sepsis assays and $40 \%$ under lethal sepsis assays in the presence of nanoformulated clavanin A until the seventh day of the experiment [52].

\subsubsection{Cadiolides}

Cadiolides C-F (29-32), butenolide metabolites (Figure 9), were isolated from the tunicate Pseudodistoma antinboja by activity-guided fractionations [53]. These compounds were evaluated for their antibacterial activity, and most of them exhibited moderate to significant activity that selectively targeted Gram-positive strains (S. aureus, S. epidermidis, Kocuria rhizophila and B. subtilis; MIC $=0.2-12.5 \mu \mathrm{g} / \mathrm{mL}$ ). However, they did not show inhibitory activity toward the Gram-negative bacteria. Cadiolides C-F (29-32) was also showed antibacterial activities with methicillin-sensitive S. aureus (MSSA) and methicillin-resistant S. aureus (MRSA) ranging from 0.13 to $4 \mu \mathrm{g} / \mathrm{mL}$ of MICs [53]. In addition, it should be noted that none of these compounds showed significant cytotoxicity in the MTT assay at $100 \mu \mathrm{M}$. Therefore, cadiolides could serve as new lead compounds for the development of antibiotics for the treatment of bacterial infections caused by Gram-positive bacteria, such as $S$. aureus [53]. 


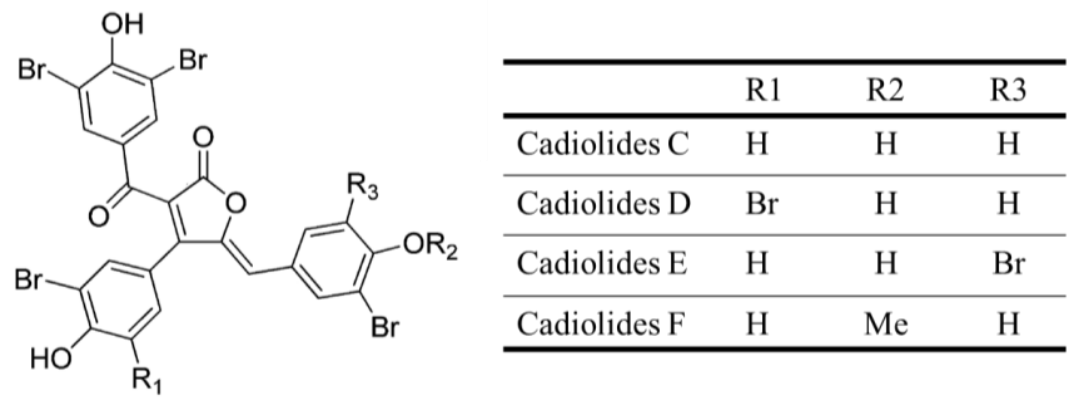

Figure 9. Structure of Cadiolides (29-32). Caldiolides were isolated from the tunicate Pseudodistoma antinboja by activity-guided fractionations [53].

\subsubsection{Cytosporones B and E}

Cytosporomes B (33) and E (34) isolated a strain of the endophytic fungus Leucostoma persoonii from red mangrove, Rhizophora mangle [54] (Figure 10). Cytosporone B (33) demonstrated a 4.2-fold reduction in bacterial viability and at twice the MIC, resulted in complete killing of the bacteria. Furthermore, at MIC, a 2-fold reduction in biofilm formation was observed, and at twice the MIC, 168-fold reduction occurred. At higher concentrations, it appears strongly active toward biofilms, which is uncommon for antibiotics; however, cytosporone B is cytotoxic toward A549 cells (TI90 = IC90 $\mathrm{A}_{\left.549 / \mathrm{MIC}_{90}=6\right)}$ [54]. Cytosporone E (34) was equipotent against USA100 and methicillin-sensitive S. aureus (MSSA) strains $(72 \mu \mathrm{M})$, indicating the intrinsic drug resistant properties of MRSA strains are not helpful in resisting the action of this cytosporone. In addition, at MIC, it resulted in >5000-fold reduction in bacterial viability, indicating it is strongly bactericidal, and not just bacteriostatic. The

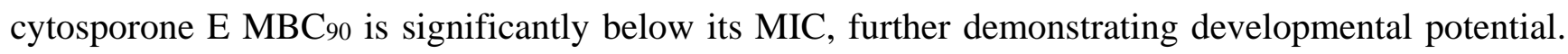
Cytosporone $\mathrm{E}$ is also cytotoxic, but reasonably selective for bacteria relative to mammalian cells $\left(\mathrm{TI}_{90}=10\right)$. Cytosporone $\mathrm{E}(\mathbf{3 4})$, however, displayed an $\mathrm{IC}_{90}$ of $13 \mu \mathrm{M}$, which represents significant selectivity $\left(\mathrm{TI}_{90}=33\right)$ for a moderately potent antimalarial drug [54].<smiles>CCCCC(=O)c1c(O)cc(O)cc1CC(=O)OCC</smiles>

Cytosporone B (33)<smiles>CCCCCCC1OC(=O)c2cc(O)c(O)c(O)c21</smiles>

Cytosporone D (34)

Figure 10. Structure of cytosporomes B (33) and E (34). Cytosporomes were isolated a strain of the endophytic fungus Leucostoma persoonii [54].

\subsubsection{Anthracimycin}

Anthracimycin (35), a chemical compound derived from the Steptomyces bacteria, was discovered in the ocean off the coast of Santa Barbara in California [55]. It has shown significant activity against 
B. anthracis, Enterococcus faecalis, Streptococcus pneumonia and S. aureus including MSSA, MRSA and vancomycin-resistant strains of $S$. aureus at MIC value between 0.03125 and $0.25 \mu \mathrm{g} / \mathrm{mL}$. At concentrations near the MIC, anthracimycin inhibited $S$. aureus nucleic acid synthesis as determined by optimized macromolecular synthesis methodology, with inhibition of DNA and RNA synthesis occurring in the absence of DNA intercalation. Anthracimycin at a single dose of 1 or $10 \mathrm{mg} / \mathrm{kg}$ was able to protect mice from MRSA-induced mortality in a murine peritonitis model of infection. Anthracimycin provides an interesting new scaffold for future development of a novel MRSA antibiotic [55] (Figure 11).

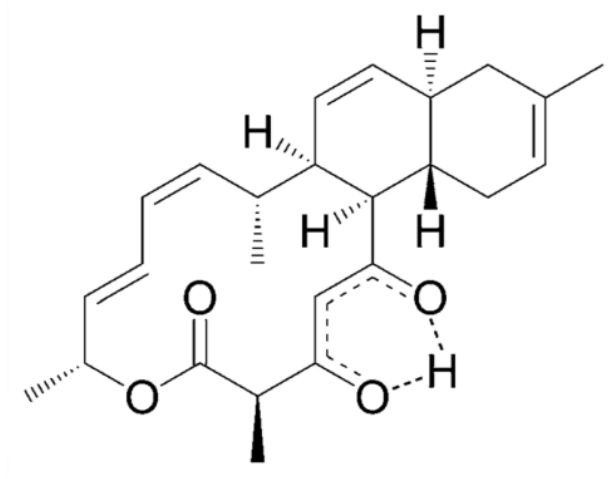

Figure 11. Structure of Anthracimycin (35). Anthracimycin were isolated from the Steptomyces bacteria [55].

\subsection{Antifungal Activity}

Pathogenic fungi cause diseases in humans and other organisms. Candida species are important human pathogens that are best known for causing opportunistic infections in immunocompromised hosts (e.g., transplant, AIDS, and cancer patients). Aspergillus can cause disease through the production of mycotoxins through the induction of allergenic responses and through localized or systemic infections. Aspergillus flavus produces aflatoxin, which is a carcinogen. Cryptococcus neoformans can cause severe forms of meningitis and meningo-encephalitis in patients with HIV infection and AIDS [97]. Fungal infections in humans range in severity from easily treated superficial infections of the skin and hair to life threatening disseminated infections that involve multiple organ systems. Among fungal infections (mycoses), crytococcosis and candidiasis, whether systemic (affecting deeper tissues and organs) or superficial (affecting skin, nails, scalp or mucous membrane), are serious problems in public health. Although fungi have existed for millions of years, their role in causing infections in humans was not recognized until the 1830s to 1840s. Early treatment modalities [98] of human infections were based on the plant mycologists' experience, and included the use of toxic reagents, such as copper, mercury, iodide, Whitefield's ointment (a combination of benzoic and salicylic acids), selenium sulfide, castellani paint, and gentian violet [97]. Griseofulvin, amphotericin B, allyl amines, and azole antifungals were developed during the 1950s to 1980s. Azole antifungals are remarkable as a drug class for their broad-spectrum targeting, oral bioavailability, and lower toxicity, as compared to other antifungals, such as polyenes (e.g., nystatin) and pyrimidines (e.g., 5-flucytosine). Nevertheless, new compounds being developed as resistance to azoles is slowly emerging, particularly in C. albicans. Diverse protein classes have emerged as novel, potent natural therapeutics. Prominent among metabolites with wide bioactivities in recent years are cyclic peptides, especially members of echinocandin family [99]. This 
suggests that, in principle, new antifungal agents based on peptidic structures are developing. From 2006 to the present, 18 studies reported antifungal marine peptides isolated from a diverse group of marine bacteria, ascidians, sponges and mollusk.

\subsubsection{Halocidin}

Jang et al. found that a synthetic analog of halocidin (36), a previously reported antimicrobial peptide isolated from the hemocytes of a marine ascidian, had potent antifungal activity (MIC $=1-4 \mu \mathrm{g} / \mathrm{mL}$ ) [56]. The synthetic Di-K19Hc peptide was shown to bind C. albicans rapidly (30 s) via an interaction with $\beta$-1,3-glucan, a component of the fungal cell wall, and concomitantly inducing ion channel formation, $\mathrm{K}^{+}$efflux, and death of the fungal cell. Halocidin is composed of two subunits, containing 18 and 15 amino acid residues joined by a single disulfide bond (Figure 12). An antimicrobial assay performed with synthetic congeners of halocidin containing the 18-residue monomer, showed that this subunit is more active than the heterodimer or the 15-residue monomer against MRSA and multi-drug resistant P. aeruginosa [100].

\section{WLNALLHHGLNCAKGVLA*-NH ALLHHGLNCAKGVLA*-NH}

Figure 12. Amino acid sequence of halocidin (36). Halocidin were identified from the hemocytes of Hyas araneus [56]. Vertical bars in the sequence indicate a disulfide bond between two cysteine residues. The asterisk (*) denotes $C$-terminal amidation.

\subsubsection{Callipeltins $\mathrm{J}$ and $\mathrm{K}$}

Callipeltins are a group of marine peptides with unusual structural features and remarkable biological properties, isolated from the sponges Callipelta sp. [57]. From a structural point of view, the most distinctive feature of callipeltins is the presence of several non-proteinogenic units. Callipeltins K (37) and J (38) inhibit the growth of C. albicans ATCC 24433 in a standard disk assay with MIC value of $10^{-4} \mathrm{M}$. The antibiotic mixture selectively inhibited the growth of fungus, among which C. albicans $(\mathrm{MIC}=1 \mu \mathrm{M})$ was the most affected [57].

\subsubsection{Pedein A}

The cyclopeptide pedein A (39) is an antifungal peptides from the myxobacterium Chondromyces pediculatus. These cyclic peptides are notably composed of (6-chloro)-Trp, Gly, and several unusual amino acids. Pedein A inhibits many yeasts and fungi, especially C. albicans and Rhizopus arrhizus. (MIC $=0.6-1.6 \mu \mathrm{g} / \mathrm{mL}$ ) [58]. Hopefully, future studies will evaluate the mechanism of action of these marine compounds. 


\subsubsection{Theonellamide}

Nishimura and colleagues evaluated the pharmacology of the bicyclic antifungal dodecapeptide theonellamide F (40), previously isolated from a sponge Theonella sp. [59]. Chemical-genomic profiling analysis, together with detailed subcellular localization studies, determined that the antifungal theonellamides represent a new class of sterol-binding molecules that induce membrane damage and activate Rhol-mediated 1,3- $\beta$-D-glucan synthesis.

Theonellamide G (41) showed potent antifungal activity towards wild and amphotericin B-resistant strains of $C$. albicans, with $\mathrm{IC}_{50}$ s of 4.49 and $2.0 \mu \mathrm{M}$, respectively. Additionally, it displayed cytotoxic activity against the human colon adenocarcinoma cell line (HCT-16) with an IC50 of $6.0 \mu \mathrm{M}$. These findings provide further insight into the chemical diversity and biological activities of this class of compounds [60].

\subsubsection{Theopapuamides}

Theopapuamides B (42) and C (43) were isolated from the Indonesian marine sponge Siliquariaspongia mirabilis [61]. Theopapuamide B (42) was active in a neutralization assay, with an $\mathrm{IC}_{50}$ value of $0.8 \pm 0.3 \mu \mathrm{g} / \mathrm{mL}$. Theopapuamides $\mathrm{B}$ and $\mathrm{C}$ showed cytotoxicity against human colon carcinoma (HCT-116) cells with $\mathrm{IC}_{50}$ values between 2.1 and $4.0 \mu \mathrm{g} / \mathrm{mL}$, and exhibited strong antifungal activity against wild-type and amphotericin B-resistant strains of $C$. albicans at loads of 1-5 $\mu \mathrm{g} / \mathrm{disk}$ [61].

\subsubsection{Surfactin}

Surfactin is a lipopeptide biosurfactant with a broad spectrum of antimicrobial and antiviral activity. Surfactins have a peptide backbone composed of seven amino acids connected to a $\beta$-hydroxy fatty acid, which may vary from C-10 to C-16 [62] (Figure 13).

$\mathrm{C}(15)$-surfactin (44) from B. amyloliquefaciens $(6.25 \mu \mathrm{g} / \mathrm{mL})$ synergized with the antifungal drug ketoconazole $(0.004 \mu \mathrm{g} / \mathrm{mL})$ to inhibit $C$. albicans SC5314. Optimum production of C(15)-surfactin $(134.2 \mathrm{mg} / \mathrm{L})$ with a 1.52 -fold increase was achieved by employing response surface methodology in shaker flask cultivation in medium [101].

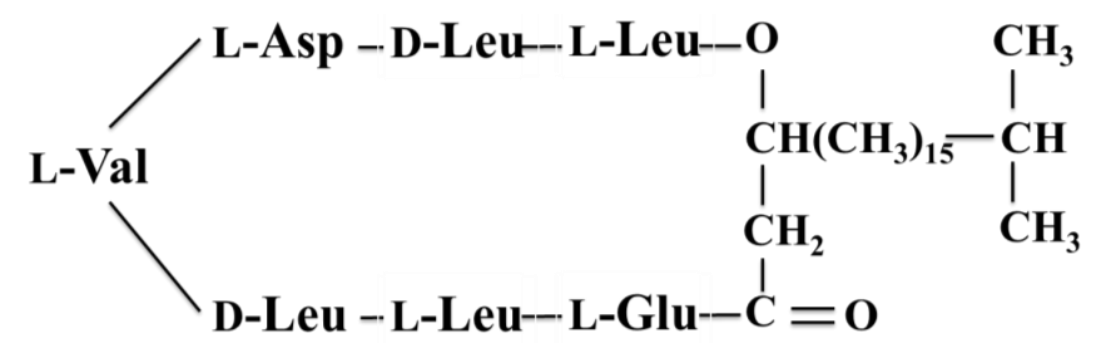

Figure 13. Structure of C(15)-surfactin (44). Surfactin was isolated from Bacillus amyloliquefaciens [101].

\subsubsection{Anti-CA Cyclic Lipopeptide}

Anti-CA (45) from the bacterium B. amyloliquefaciens, isolated from a mangrove system, manifested fungicidal activity against a clinical strain of $C$. albicans. The main bioactive substance was a cyclic 
lipopeptide containing a heptapeptide, Asp-Leu-Leu-Val-Val-Glu-Leu, and a 3-OH fatty acid with 15 carbon atoms. The lipopeptide also killed other yeast strains including C. tropicalis, Metschnikowia bicuspidata, Saccharomyces cerevisiae, and Yarrowia lipolytica [63].

\subsubsection{Maribasins A and B}

Two new cyclic lipopeptides, maribasins A (46) and B (47), were obtained from the fermentation broth of the marine microorganism B. marinus B-9987, which was isolated from Suaeda salsa from the Bohai coastline of China. The compounds displayed the structures cyclo (D-Pro-L-Gln-L-Asn-L-Ser-D-Asn1-D-Tyr-D-Asn2-D- $\beta$-aminoisopentadecanoic acid) and cyclo (D-Pro-L-Gln-L-Asn-L-Ser-D-Asn1-D-Tyr-D-Asn2-D- $\beta$-aminoanteisopentadecanoic acid), respectively. The lipopeptides demonstrated activity against a spectrum of phytopathogenic fungi [64].

\subsubsection{Mojavensin A}

Three lipopeptides, designated as mojavensin A (48) were isolated from the fermentation broth of Bacillus mojavensis B0621A. Mojavensin A was characterized by a peptide backbone of L-Asn(1), D-Tyr(2), D-Asn(3), L-Gln(4), L-Pro(5), D-Asn(6), L-Asn(7), and an anteiso-type of saturated $\beta$-fatty acid side chain. These lipopeptides displayed dose-dependent antifungal activity against a broad spectra of phytopathogens, as well as being weakly antagonistic to $S$. aureus. Moreover, they all displayed cytotoxic activities against a human leukemia cell line (HL-60) with $\mathrm{IC}_{50}$ values of 100, 100, and $1.6 \mu \mathrm{M}$, respectively [65].

\subsubsection{Kahalalides}

Another well-characterized, unusual group of peptides are the kahalalides, a family of depsipeptides with variable size and peptide series, ranging from C31 (tripeptide) to C77 (tridecapeptide) and carrying different fatty acid chains [66]. Hill et al. suggested that the Hawaiian sea slug Elysia rufescens acquires kahalalide-producing microbes from the surface of Bryopsis, and then retains these microbes as symbionts. Kahalalides, especially kahalalide $\mathrm{F}$ (49), are active against several fungi, such as $C$. albicans $\left(\mathrm{IC}_{50}=3.02 \mu \mathrm{M}\right), C$. neoformans ( $\mathrm{IC}_{50}=1.53 \mu \mathrm{M}$ ), Mycobacterium intracellulare, and A. fumigates $\left(\mathrm{IC}_{50}=3.21 \mu \mathrm{M}\right)$ [102]. Their chemical synthesis has made it possible to characterize structure-activity relationships, resulting in the synthesis of derivatives with increased biological activity.

\subsubsection{Miuraenamides}

Marine myxobacteria are rare, culture-resistant microorganisms, several strains of which have been identified by research groups in Asia. Paraliomyxa miuraensis, a slightly halophilic myxobacterium discovered in Japan, produces the cyclic hybrid polyketide-peptide antibiotics known as miuraenamide A (50) and B (51) [67]. Miuraenamide A and B are cyclic depsipeptides that possess one halogenated $N$-methyl-Tyr, one dehydro-Phe, and one Ala. Miuraenamides A and B are active against several fungi, such as Phytophthora capsici ( $\left.\mathrm{IC}_{50}=0.4 \mu \mathrm{M}\right)$, A. niger $\left(\mathrm{IC}_{50}=50 \mu \mathrm{M}\right)$, Rhizopus oryzae $\left(\mathrm{IC}_{50}=6.3 \mu \mathrm{M}\right)$, and $C$. rugosa $\left(\mathrm{IC}_{50}=12.5 \mu \mathrm{M}\right)[68]$. The mechanism of miuraenamide synthesis has not yet been elucidated. 


\subsubsection{Callyaerin}

Callyaerins are cytotoxic cyclic peptides from the Indonesian marine sponge Callyspongia aerizusa [69]. Callyaerin A (52) exhibited strong inhibitory properties towards C. albicans and moderate activity against gram-negative $E$. coli, while it was only mildly active or inactive against gram-positive S. aureus and B. subtilis, respectively. Callyaerin E (53) displayed strong antimicrobial activity towards C. albicans and B. subtilis, but was only mildly active against the two remaining bacterial strains [69].

\subsection{Anti-Malarial Activity}

Malaria is the most threatening parasitic infection in humans. Each year, between 300 and 500 million new clinical cases are reported by the World Health Organization [103], resulting in annual deaths of approximately one million people [104], of which 75\% are children below five years of age [105]. The most exposed continent is Africa; however, Southeast Asia, Oceania, and Central and South America are also under severe threat. Among the most affected are developing nations, which suffer from health care systems that lack the necessary infrastructure to cope with such diseases.

There are four species of Plasmodium infecting humans: Plasmodium falciparum, Plasmodium vivax, Plasmodium ovale, and Plasmodium malariae, but most malaria cases are caused by the protozoan parasite P. falciparum [106]. The parasite is transmitted by Anopheles mosquitos. Therefore, malaria can be controlled, to some extent, by conventional prevention strategies, such as mosquito repellents, mosquito traps, insecticides, or biological control. The introduction of efficient vaccines is still problematic, despite recent progress in this area [107]. As a direct consequence, the treatment of choice remains parasite chemotherapy with small molecule drugs, both of natural origin or synthetic $[108,109]$. In parallel, resistance to commonly used anti-malarial therapeutics is growing. Thus, there is an urgent need to develop new drugs against this disease. Moreover, combination treatment should be explored to reduce the risk of resistance. For example, combinations of artemisinin-amodiaquine and the artemether-lumefantine (Coartem) have been used. Contributing to the global search for novel antimalarial peptides, and as presented in Table 1, eleven novel marine peptides were shown to possess antimalarial activity between 2006 and the present.

\subsubsection{Dragomabin}

McPhail et al. reported two marine cyanobacterial metabolites [70]. New linear alkynoic lipopetides, dragomabin (54) and dragonamide B, have been isolated from a red Panamanian strain of the marine cyanobacterium Lyngbya majuscula [65]. Dragomabin (54) showed good antimalarial activity $\left(\mathrm{IC}_{50}=6 \mu \mathrm{M}\right)$ against chloroquine-resistant Plasmodium falciparum, whereas the nonaromatic analogue, dragonamide $\mathrm{B}$, was inactive.

\subsubsection{Venturamides}

Linington et al. [71] discovered the new cyclic hexapeptides venturamide A (55) and B (56), which were isolated from a Panamanian marine cyanobacterium Oscillatoria sp. These modified cyclic hexapeptides showed moderate selectivity for parasites versus mammalian host cells. Venturamide A (55) showed in vitro activity against W2 chloroquinone-resistant Plasmodium falciparum ( $\left.\mathrm{IC}_{50}=8.2 \mu \mathrm{M}\right)$, 
with only mild cytotoxicity to mammalian Vero cells $\left(\mathrm{IC}_{50}=86 \mu \mathrm{M}\right)$. Venturamide B $(\mathbf{5 6})$ also showed low micromolar antimalarial activity against Plasmodium falciparum ( $\mathrm{IC}_{50}=5.6 \mu \mathrm{M}$ ) and mild cytotoxicity to mammalian Vero cells $\left(\mathrm{IC}_{50}=56 \mu \mathrm{M}\right)$. The mode of action of these compounds is yet unknown.

\subsubsection{Aerucyclamides}

Four new haxacyclopeptides, aerucyclamides A-D (57-60), were isolated from the cyanobacterium Microcystis aeruginosa PCC 7806, and their structural characterization, synthesis, and biological activity have been reported [72,73]. All four aerucyclamides were evaluated for anti-plasmodial activity. The most active compound was aerucyclamide B (58), which displayed a submicromolar $\mathrm{IC}_{50}$ value of $0.7 \mu \mathrm{M}$ against the chloroquine-resistant Plasmodium falciparum strain K1. In addition, this compound displays a large selectivity for the parasite in L6 rat myoblasts, with an $\mathrm{IC}_{50}$ value of $120 \mu \mathrm{M}$. Interestingly, a reduction of the thiazole to a thiazoline (structural modification from A to B) decreases the antiplasmodial activity by 1 order of magnitude. Similar aerucyclamides C (59) and D (60) $\left(\mathrm{IC}_{50}=2.3\right.$ and $6.3 \mu \mathrm{M}$, respectively) had low micromolar activities.

\subsubsection{Gallinamide A}

Portmann et al. purified a novel linear peptide, gallinamide A (61), from a cyanobacterium Schizothrix sp. with an unusual 4-(S)-amino-2-(E)-pentenoic acid and methylmethoxy-pyrrolinone at the $C$-terminus [74]. Gallinamide A was moderately active against the chloroquinone-resistant Plasmodium falciparum strain W2 and Leishmania donovani $\left(\mathrm{IC}_{50}=8.4 \mu \mathrm{M}\right)$. Further, its structure has been deemed an "attractive foundation for further SAR investigations" [74].

\subsubsection{Lagunamide A and B}

Tripathi et al. found two new cyclic depsipeptides, lagunamides A (62) and B (63), in the Singaporean marine cyanobacterium Lyngbya majuscule, which had potent antimalarial activity $\left(\mathrm{IC}_{50}=0.19-0.91 \mu \mathrm{M}\right)$ against the drug-sensitive Plasmodium falciparum strain NF54 [75].

\subsubsection{Albopunctatone}

Carroll et al. isolated a new anthrone-anthraquinone, albopunctatone (64) in the $\mathrm{MeOH}$ extract of the Great Barrier Reef ascidian Didemnum albopunctatum, which had moderately antimalarial activity $\left(\mathrm{IC}_{50}=5.3\right.$ and $\left.4.4 \pm 0.5 \mu \mathrm{M}\right)$ against chloroquine-resistant (Dd2) and -sensitive strains (3d7) of Plasmodium falciparum [76]. Albopunctatone (64) was also inactive up to $40 \mu \mathrm{M}$ when tested against a variety of cancerous and normal human cell lines and the kinetoplastid Trypanosoma brucei brucei, indicating selectivity for the malaria parasite, P. falciparum [76] (Figure 14).

\subsection{Antiprotozoal Activity}

Seventeen marine peptides were reported to possess antimicrobial activity against other protozoa, thus contributing to the ongoing global search for novel agents to treated so-called neglected diseases, including Leishmaniasis (caused by several species of the genus Leishmania), amoebiasis, 
trichomoniasis, African sleeping sickness (caused by Trypanosoma brucei rhodesiense and Trypanosoma brucei gambiense) and American sleeping sickness or Chagas disease (caused by Trypanosoma cruzi).<smiles>O=C1c2cccc(O)c2C(=O)c2c1ccc(C1(O)c3cccc(O)c3C(=O)c3c(O)cccc31)c2O</smiles>

Figure 14. Structure of albopunctatone (63). Albopunctatone was isolated ascidian Didemnum albopunctatum [76].

\subsubsection{Viridamides}

An investigation of the marine cyanobacterium Oscillatoria nigro-viridis from Panama led to the isolation of two novel bioactive lipopeptides, viridamides A (65) and B (66) [77]. Viridamide A was tested against a series of relevant tropical pathogens and cancer cell lines, and displayed significant activity against the parasitic protozoan Plasmodium falciparum $\left(\mathrm{IC}_{50}=5.8 \mu \mathrm{M}\right)$. Further, viridamide A also exhibited activity against Leishmania mexicana $\left(\mathrm{IC}_{50}=1.1 \mu \mathrm{M}\right)$ and Trypanosoma cruzi $\left(\mathrm{IC}_{50}=1.5 \mu \mathrm{M}\right)$.

\subsubsection{Almiramides}

Sanchez et al. isolated two novel linear lipopeptides, almiramides B (67) and C (68), from the marine cyanobacterium Lyngbya majuscule. Almiramides $\mathrm{B}$ and $\mathrm{C}$ displayed strong antiparasitic activity against Leishmania donovani $\left(\mathrm{IC}_{50}=1.9-2.4 \mu \mathrm{M}\right)$ with minimal cytotoxicity towards Vero cells $\left(\mathrm{IC}_{50}=33.1-52.3 \mu \mathrm{M}\right)$ [78], whereas Almiramides A was inactive up to $13.5 \mu \mathrm{M}$, indicating the requirement of an unsaturated terminus in the side chain for the activity [78].

\subsubsection{Valinomycin}

Pimentel-Elardo et al. reported the isolation of the known cyclic depsipeptide valinomycin (69) from marine Streptomyces sp. strains associated with several Croatian marine sponges, and observed significant activity against both Trypanosoma brucei $\left(\mathrm{IC}_{50}=0.0032 \mu \mathrm{M}\right)$ and Leishmania major $\left(\mathrm{IC}_{50}<0.11 \mu \mathrm{M}\right)[79]$.

\subsubsection{Diketopiperazines}

Watts et al. reported the crude extracts of two fungal strains (A. fumigatus and Nectria inventa) isolated from deep water sediment which provided $>99 \%$ growth inhibition at $1 \mu \mathrm{g} / \mathrm{mL}$ of Trypanosoma brucei, the causative parasite of Human African trypanosomiasis (HAT, commonly 
known as African sleeping sickness) [80]. The saltwater Aspergillus culture presented five compounds: bis(methylthio)gliotoxin (70), its dehydro derivative (71), 6-methoxyspirotryprostatin B (72), verruculogen TR-2 (73), and cyclotryprostatin A (74). Unexpectedly, the deionized water culture of this strain produced three different metabolites: verruculogen (75), fumitremorgin B (76) and 12,13-dihydroxyfumitremorgin $\mathrm{C}$ (77). The deionized water culture of $N$. inventa was a source of four sulfur-containing nitrogen-containing diketopiperazines: chetoseminudin B (78), 3,6-bis(methylthio)-cyclo(alanyltryptophyl) (79), verticillin B (80) and chaetocin (81) (Figure 15). Twelve of the compounds, each containing a diketopiperazine core, showed excellent activity against T. brucei $\left(\mathrm{IC}_{50}=0.002-40 \mu \mathrm{M}\right)$, with selectivity over mammalian cells as great as 20 -fold [80]. The trypanocidal diketopiperazines were also tested against two cysteine protease targets. Rhodesain and TbCatB, where five compounds showed inhibition activity at concentrations less than $20 \mu \mathrm{M}$. [80].

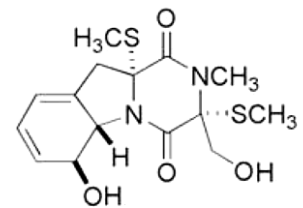

bis(methylthio)gliotoxin

(70)

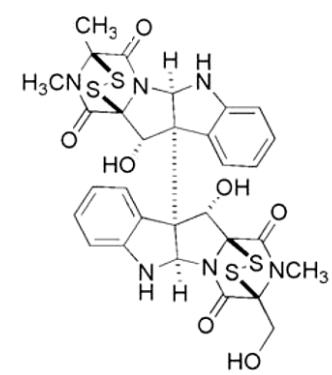

Verticilin B (80)

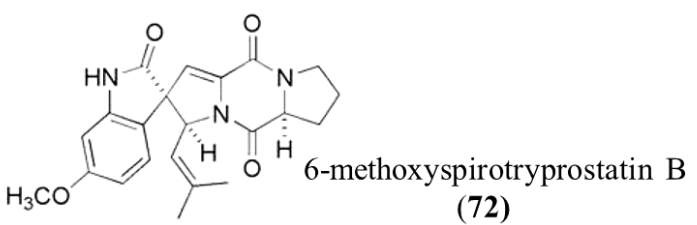

(72)

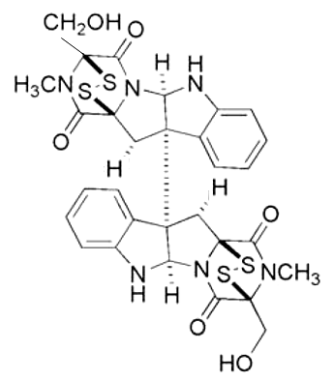

Chaetocin (81)

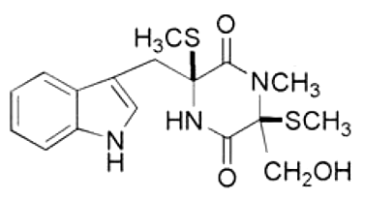

Chetoseminudin B

(78)

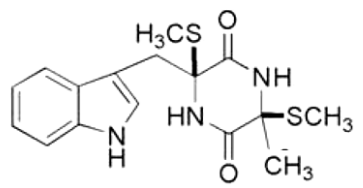

3,6-bis(methylthio) -cyclo(alanyltryptophyl)

(79)

\begin{tabular}{|c|c|c|}
\hline Verruculogen TR-2 (73) & $\mathrm{H}$ & $R$ \\
\hline Fumitremorgin (76) & & $R$ \\
\hline $\begin{array}{l}\text { 12,13- } \\
\text { dihydroxyfumitremorgin } \\
(77)\end{array}$ & $\mathrm{H}$ & $R$ \\
\hline Cyclotryprostatin A (74) & & $S$ \\
\hline
\end{tabular}

Figure 15. Structure of diketopiperazines (70-81) [80].

\subsection{Antituberculosis Activity}

Antituberculosis agents are drugs used to treat tuberculosis, an infectious disease caused by Mycobacterium tuberculosis. This infection mainly affects the lungs, but can also affect many other organ systems. Many classes of drugs with different mechanism of action have activity against M. tuberculosis. As shown in Table 1, one paper (three compounds) reported work regarding anti-tuberculosis pharmacology with marine peptides from 2006 to the present. 


\section{Trichoderins}

Three new aminolipopeptides, trichoderins A $(\mathbf{8 2})$, A1 $(\mathbf{8 3})$, and B (84), were isolated from a culture of the marine sponge-derived fungus Trichoderma sp. as anti-mycobacterial substances with activity against active and dormant bacilli [106]. Trichoderins showed potent antimycobacterial activity against Mycobacterium smegmatis, Mycobacterium bovis, and Mycobacterium tuberculosis under standard aerobic growth conditions, as well as dormancy-inducing hypoxic conditions, with MIC values in the range of $0.02-2 \mu \mathrm{g} / \mathrm{mL}[81]$.

\subsection{Anti-Viral Activity}

Influenza continues to be a danger to human and animal health. The ability of the virus to undergo rapid mutation means that antigenic variants constantly arise, breeching the host-adaptive immune response. Pathogenic variants may arise at any time, and through reassortment, can generate new subtypes with the potential to cause pandemics. Approaches to broaden the availability of novel antiviral compounds include the development of synthetic peptides that disrupt the entry of the virus into cells. Antiviral peptides have been developed against hepatitis C [110], West Nile virus [111], respiratory syncytial virus [112], human immunodeficiency virus (HIV) [113], and the influenza virus [114]. The clinical application of the peptide Enfuvirtide (FUZEON), which blocks the entry of HIV into cells, points to the success of peptide-based therapies in a clinical setting. Other key therapeutic peptides include bivalirudin (Angiomax), a platelet aggregation inhibitor peptide, and abarelix (Plenaxis), a gonadotropin-releasing hormone $(\mathrm{GnRH})$ antagonist. These are typical of the new generation of peptides with excellent therapeutic efficacy.

As shown in Table 1, thirty reports were published from 2006 to the present on the antiviral pharmacology of novel marine peptides against human cytomegalovirus and herpes simplex virus. Three articles reported preclinical pharmacology of marine compounds active against the human immunodeficiency virus type-1 (HIV-1), the causative agent of the acquired immunodeficiency disease syndrome (AIDS).

\subsubsection{Mirabamides A, C, and D}

Plaza et al. described three cyclic depsipeptides, mirabamides A (85), C (86) and D (87), isolated from the sponge Siliquariaspongia mirabilis [82]. Mirabamides contain two entities, including 4-chloromoproline in 1-3 and an unusual glycosylated amino acid, $\beta$-methoxytyrosine 4'-O- $\alpha$-L-rhamnopyranoside (in 1, 2 and 4), along with a rare $N$-terminal aliphatic hydroxy acid. Mirabamide A (85) inhibited HIV in neutralization and fusion assays with $\mathrm{IC}_{50}$ values between 40 and $140 \mathrm{nM}$, as did mirabamides C (86) and D (87) (IC 50 values between $140 \mathrm{nM}$ and $1.3 \mu \mathrm{M}$ for C and $190 \mathrm{nM}$ and $3.9 \mu \mathrm{M}$ for D), indicating that these peptides can act at the early stages of HIV-entry. Additionally, mirabamides A and C inhibited the growth of B. subtilis and C. albicans at $1-5 \mu \mathrm{g} / \mathrm{disk}$ in a disk diffusion assays [82].

Four other homogenous depsipeptides, mirabamides E-H (88-91), from the sponge Stelletta clavosa also showed strong inhibition of HIV-1 in a neutralization assay using the viral strain YU2-V3 with IC50 
values of $121,62,68$, and $41 \mathrm{nM}$, respectively [115]. The primary feature distinguishing mirabamides $\mathrm{E}-\mathrm{H}$ from mirabamides $\mathrm{A}, \mathrm{C}$, and $\mathrm{D}$ was the presence of 2-amino-2-butenoic acid in place of threonine.

\subsubsection{Mollamide B}

Mollamide B (92) is a cyclic hexapeptide isolated from the Indonesian tunicate Didemnum molle. Mollamide B exhibited moderate antimalarial activity against $P$. falciparum (D6 clone and W2 clone), with $\mathrm{IC}_{50}$ values of 2.0 and $2.1 \mu \mathrm{g} / \mathrm{mL}$, respectively. Further, mollamide B also exhibited marginal activity against Leishmania donovani, with $\mathrm{IC}_{50}$ and $\mathrm{IC}_{90}$ values of 18 and $35 \mu \mathrm{g} / \mathrm{mL}$, respectively, and against HIV-1 in human PBM cells with an $\mathrm{EC}_{50}$ value of $48.7 \mu \mathrm{M}$ [83].

Mollamide B was examined for antimicrobial activity against MRSA, Mycobacterium intracellulaire, C. albicans, C. glabrata, C. krusei, and C. neoformans, and exhibited no activity. Mollamide B has shown no anti-inflammatory activity in rat neonatal microglia, and did not inhibit cyclooxygenase-2 (COX-2) activity in a cell-based assay [116].

\subsubsection{Papuamides}

Papuamides are a class of marine sponge-derived cyclic depsipeptides, which are thought to have cytoprotective activity against HIV in vitro through the inhibition of viral entry [84]. Papuamide A (93) is a novel marine compound isolated from the sponge Theonella sp. Papuamide A was tested in a fusion assay and against the HCT-116 cell line, with IC50 values of $73 \mathrm{nM}$ and $3.5 \mu \mathrm{M}$. The anti-HIV activity of papuamide was shown to occur through a membrane-targeting mechanism, in which the hydrophobic tail of the molecule inserts into the viral membrane and the tyrosine residue interacts with cholesterol [84].

\subsubsection{Celebesides $\mathrm{A}$ and $\mathrm{C}$}

Plaza et al. isolated several new cyclic depsipeptides from the Indonesian marine sponge Siliquariaspongia mirabilis, including celebesides A (94) and C (95), which inhibited HIV-1 in an infectivity assay $\left(\mathrm{IC}_{50}=1.9 \pm 0.4 \mu \mathrm{g} / \mathrm{mL}\right)$ [61]. Celebeside A was active against both $\mathrm{HIV}-1$ $\left(\mathrm{IC}_{50}=0.002 \mu \mathrm{M}\right)$ and HCT 116 cancer cells $\left(\mathrm{IC}_{50}=0.009 \mu \mathrm{M}\right)[61]$. The lipid component of celebeside $\mathrm{A}$ is of mixed origin. Celebesides A and C were tested against HCT-116 cells, giving IC 50 values of 9.9 and $>31 \mu \mathrm{M}$, respectively. The ability to inhibit HIV-1 entry was also evaluated for both celebeside A and $\mathrm{C}$, with $\mathrm{IC}_{50}$ values of 2.1 , and $>62 \mu \mathrm{M}$, respectively. Interestingly, for both celebesides $\mathrm{A}$ and $\mathrm{C}$ in biological assays, loss of activity was correlated with the loss of the phosphate group.

\subsubsection{Theopapuamides}

Theopapuamide A (96) is a cytotoxic undecapeptide isolated from Theonella swinhoei collected in Milne Bay, Papua New Guinea [85]. It is the first natural peptide containing $\beta$-methoxyasparagine and 4-amino-5-methyl-2,3,5-trihydroxyhexanoic acid residues. It was tested in the CEM-TART (T-cells that express both HIV-1 tat and rev) and HCT-116 colorectal carcinoma cell lines with IC50 values of 0.5 and $0.9 \mu \mathrm{M}$, respectively. 
Plaza et al. isolated cyclic peptides, theopapuamides B (42), C (43), and D (97), from an extract of Siliquariaspongia mirabilis collected off Sulawesi Island, Indonesia [61]. Theopapuamides B (41) and $\mathrm{C}$ (42) were tested against HCT-116 cells giving $\mathrm{IC}_{50}$ values of 2.5 and $1.3 \mu \mathrm{M}$, respectively. The ability to inhibit HIV-1 entry was also evaluated for theopapuamides B (42), with $\mathrm{IC}_{50}$ values of $0.5 \mu \mathrm{M}$. Theopapuamides A (96), B (42), and C (43) were evaluated for their ability to inhibit the growth of both wild type and amphotericin B-resistant strains of C. albicans. Theopapuamide A inhibited the growth of both strains with zones of inhibition of $8 \mathrm{~mm}$ at $1 \mu \mathrm{g} / \mathrm{disk}$, while theopapuamides $\mathrm{B}$ and $\mathrm{C}$ displayed zones of $10 \mathrm{~mm}$ against both strains at $5 \mu \mathrm{g} / \mathrm{disk}$ [61].

\subsubsection{Asperterrestide A}

Asperterrestide A (98), a cyclic tetrapeptide with a rare 3-OH- $\mathrm{N}-\mathrm{CH}_{3}-\mathrm{Phe}$ residue, was isolated from the fermentation broth of the marine-derived fungus Aspergillus terreus SCSG AF0162. Asperterrestide A showed inhibitory effects on influenza virus strains A/WSN/33 (H1N1) (an M2-resistant strain) and strain A/Hong Kong/8/68(H3N2) (an M2-sensitive strain), with $\mathrm{IC}_{50}$ values of 20.2 and $0.41 \mu \mathrm{M}$, respectively. Cytotoxic activity was tested in U937 and MOLT4 human carcinoma cell lines with $\mathrm{IC}_{50}$ values of 1.9 and $1.8 \mathrm{nM}$, respectively [86].

\subsubsection{Homophymine A}

Homophymines A-E (99-103) and A1-E1 (104-108) are a series of cyclodepsipeptides isolated from Homophymia sp. collected from shallow waters off the east coast of New Caledonia [87,88]. The anti-viral properties of Homophymines A were tested in an assay with peripheral blood mononuclear cells (PBMC) infected with the III B strain of HIV-1. Homophymine A had cytoprotective properties through the inhibition of infection production, with an $\mathrm{IC}_{50}$ value of $75 \mathrm{nM}$. Homophymine A was cytotoxic against uninfected PBMC cells with an $\mathrm{IC}_{50}$ of $1.19 \mu \mathrm{M}$, but it was almost sixteen times more effective against infected cells. Homophymines A-E and A1-E1 were evaluated against a panel of cell lines including human cancer and the Vero green monkey kidney cell lines. Homophymines A-E and A1-E1 exhibited potent cytotoxicity with $\mathrm{IC}_{50}$ values ranging from 2 to $100 \mathrm{nM}$. They were the most potent in the PC3 human prostate adenocarcinoma and the SK-OV3 human ovarian adenocarcinoma cell lines [87].

\subsubsection{Koshikamide}

The cytotoxic cyclic peptide lactone, koshikamide B (109), is the first account of a peptide possessing a carbamoylated asparagine and the new amino acid residue 2-(3-amino-2-hydroxy-5-oxopyrrolidin-2-yl) propionic acid (AHPP) [89]. It was initially isolated from a Theonella sp., collected off Shimokoshiki Island, Kagoshima Prefecture, Japan. It exhibited cytotoxicity against P388 murine leukemia and HCT-116 human colon tumor cell lines, with IC50 values of 0.22 and $3.7 \mu \mathrm{M}$, respectively (Figure 16). Koshikamides $\mathrm{F}-\mathrm{H}(\mathbf{1 1 0}-\mathbf{1 1 2}$ ) are 17-residue depsipeptides containing a 10-residue macrolactone that inhibits HIV-1 entry against a CCR5-using viral envelope, with $\mathrm{IC}_{50}$ values of 2.3 and $5.5 \mu \mathrm{M}$, respectively, whereas their linear kishikamides $\mathrm{C}$ 
were inactive [90]. Koshikamides $\mathrm{F}-\mathrm{H}$ also had moderate cytotoxicity in the HCT-116 colon cancer cell line with an $\mathrm{IC}_{50}$ of $10 \mu \mathrm{M}$. Koshikamides F-H did not inhibit the growth of $C$. albicans.

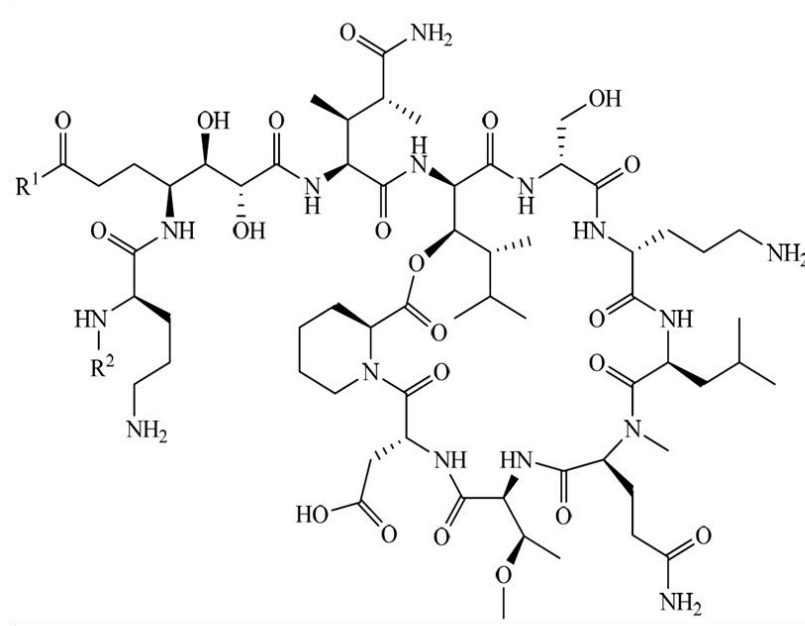

\begin{tabular}{lll}
\hline & $\mathrm{R} 1$ & $\mathrm{OH}$ \\
\hline Homophymines $\mathrm{A}$ & $\mathrm{OH}$ \\
Homophymines $\mathrm{A} 1$ & $\mathrm{NH}_{2}$ \\
\hline Homophymines $\mathrm{B}$ & $\mathrm{OH}$ \\
Homophymines $\mathrm{B} 1$ & $\mathrm{NH}_{2}$ \\
\hline Homophymines $\mathrm{C}$ & $\mathrm{OH}$ \\
Homophymines $\mathrm{C} 1$ & $\mathrm{NH}_{2}$ \\
\hline Homophymines D & $\mathrm{OH}$ \\
Homophymines D1 & $\mathrm{NH}_{2}$ \\
\hline Homophymines E & $\mathrm{OH}_{0}$ \\
Homophymines E1 & $\mathrm{NH}_{2}$
\end{tabular}

Figure 16. Structure of Homophymines A-E (99-103) and A1-E1 (104-108). Homophymines are a series of cyclodepsipeptides isolated from Homophymia sp. collected from shallow waters off the east coast of New Caledonia $[87,88]$.

\section{Conclusions}

Although marine peptides are largely unexplored, they have inherent activity and an ability to inhibit infection. Marine peptides are structurally diverse, have a wide spectrum of therapeutic action, a low bio-deposition rate in body tissues, and are highly specific to targets. Marine derived peptides also possess reduced risk of unwanted adverse side-effects. As marine peptides are composed of metabolically tolerable amino acids, they are generally safe and non-toxic. In addition to their use as active ingredients, marine peptides also have the ability to be used as excipients in drug formulations for the modification of biological activity, targeted delivery, or transport across cellular membranes. There are also a number of issues that have to be considered from the earliest stages of development when a marine chemical entity is selected for clinical development, including, the effects, sourcing, technological and scientific difficulties, and legal uncertainties. Finding new anti-infective peptides in marine living resources, particularly those living in deep-sea and special marine environments, is an important approach to identify novel active agents. Moreover, screening anti-infective activities in the existing marine peptide library, as well as semi-synthetic modifications of anti-infective agents, can be used to identify novel compounds. Extensive studies of anti-infective peptides will contribute to the generation of novel pharmaceutical products. Thus, marine peptides are a valuable source of bioactive compounds, which could be introduced for development in pharmaceutical industries.

\section{Acknowledgments}

This work was supported by a National Research Foundation of Korea (NRF) grant funded by the Global Research Laboratory (GRL) Grant (NRF-2014K1A1A2064460) and the Human Resource Training Project for Regional Innovation (NRF-2013H1B8A2032054). 


\section{Author Contributions}

All authors contributed as the same for the manuscript preparation and design.

\section{Conflicts of Interest}

The authors declare no conflict of interest.

\section{References}

1. Mayer, A.M.; Rodriguez, A.D.; Berlinck, R.G.; Fusetani, N. Marine pharmacology in 2009-2013: Marine compounds with antibacterial, antidiabetic, antifungal, anti-inflammatory, antiprotozoal, antituberculosis, and antiviral activities; affecting the immune and nervous systems, and other miscellaneous mechanisms of action. Mar Drugs 2013, 11, 2510-2573.

2. Masso-Silva, J.A.; Diamond, G. Antimicrobial Peptides from Fish. Pharmaceuticals 2014, 7, 265-310.

3. Winder, P.L.; Pomponi, S.A.; Wright, A.E. Natural Products from the Lithistida: A Review of the Literature since 2000. Mar. Drugs 2011, 9, 2643-2682.

4. Mayer, A.M.; Rodriguez, A.D.; Berlinck, R.G.; Fusetani, N. Marine pharmacology in 2007-2008: Marine compounds with antibacterial, anticoagulant, antifungal, anti-inflammatory, antimalarial, antiprotozoal, antituberculosis and antiviral activities; affecting the immune and nervous system and other miscellaneous mechanism of action. Comp. Biochem. Physiol. C Toxicol. Pharmacol. 2011, 153, 191-222.

5. Villa, F.A.; Gernwick, L. Marine natural product drug discovery: Leads for treatment of inflammation, cancer, infections and neurological disorders. Immunopharmacol. Immunotoxicol. 2010, 32, 228-237.

6. Blunt, J.W.; Copp, B.R.; Munso, M.H.; Northcote, P.T.; Prinsep, M.R. Marine natural products. Nat. Prod. Rep. 2011, 28, 196-268.

7. Zhou, X.; Liu, J.; Yang, B.; Lin, X.; Yang, X.W.; Liu, Y. Marine natural products with anti-HIV activities in the last decade. Curr. Med. Chem. 2013, 20, 953-973.

8. Kim, S.K.; Wijesekara, I. Development and biological activities of marine-derived bioactive peptides: A review. Curr. Protein Pept. Sci. 2010, 2, 1-9.

9. Ngo, D.H.; Vo, T.S.; Ngo, D.N.; Wijesekara, I.; Kim, S.K. Biological activities and potential health benefits of bioactive peptides derived from marine organisms. Int. J. Biol. Macromol. 2012, 51, 378-383.

10. Laport, M.S.; Santos, D.C.; Muricy, G. Marine sponges: Potential sources of new antimicrobial drugs. Curr. Pharm. Biotechnol. 2009, 10, 86-105.

11. Sagar, S.; Kaur, M.; Minneman, K.P. Antiviral lead compounds from marine sponges. Mar. Drugs 2010, 8, 2619-2638.

12. Cardozo, K.H.M.; Guaratini, T.; Barros, M.P.; Falcao, V.R.; Tonon, A.P.; Lopes, N.P.; Campos, S.; Torres, M.A.; Souza, A.D.; Colepicolo, P.; et al. Metabolites from algae with economical impact. Comp. Biochem. Physiol. Part C 2007, 146, 60-78. 
13. Bold, H.C.; Wynne, M.J. Introduction to the Algae Structure and Reproduction, 2nd ed.; Prentice-Hall Inc.: Englewood Cliffs, NJ, USA, 1985; pp. 1-33.

14. Garson, J. Marine natural products. Nat. Prod. Rep. 1989, 6, 143-170.

15. Nair, R.; Chabbadiya, R.; Chanda, S. Marine algae: Screening for a potent antibacterial agent. Int. J. Herb. Pharmacother. 2007, 7, 73-86.

16. Raja, A.; Vipin, C.; Aiyappan, A. Biological importance of Marine Algae-An overview. Int. J. Curr. Microbiol. Appl. Sci. 2013, 2, 222-227.

17. Nunnery, J.K.; Mevers, E.; Gerwick, W.H. Biologically active secondary metabolites from marine cyanobacteria. Curr. Opin. Biotechnol. 2010, 21, 787-793.

18. Cabrita, M.T.; Vale, C.; Router, A.P. Halogenated compounds from marine algae. Mar. Drugs 2010, 8, 2301-2317.

19. El Gamal, A.A. Biological importance of marine algae. Saudi. Pharm. J. 2010, 18, 1-25.

20. Abad, M.J.; Bedoya, L.M.; Bermejo, P. Marine Compounds and their Antimicrobial Activities. In Science against Microbial Pathogens: Communicating Current Research and Technological Advances, 1st ed.; Mendez-Vilas, A., Ed.; FORMATEX: Badajoz, Spain, 2011; Volume 51, pp. 1293-1306.

21. Ananya, A.K.; Iffat, Z.A. Cyanobacteria "the blue green algae" and its novel applications: A brief review. Int. J. Innov. Appl. Stud. 2014, 7, 251-261.

22. Tan, L.T. Bioactive natural products from marine cyanobacteria for drug discovery. Phytochemistry 2007, 68, 954-979.

23. Jaiganesh, R.; Sampath Kumar, N.S. Marine bacterial sources of bioactive compounds. Adv. Food Nutr. Res. 2012, 65, 389-408.

24. Debbab, A.; Aly, A.H.; Lin, W.H.; Proksch, P. Bioactive compounds from marine bacteria and fungi. Microb. Biotechnol. 2010, 3, 544-563.

25. Waters, A.L.; Hill, R.T.; Place, A.R.; Hamann, M.T. The expanding role of marine microbes in pharmaceutical development. Curr. Opin. Biotechnol. 2010, 21, 780-786.

26. Thomas, T.R.A.; Kaulekar, D.P.; Lokabarathi, P.A. Marine drugs from sponge-microbe association: A review. Mar. Drugs 2010, 8, 1417-1468.

27. Lu, X.; Gao, X.; Liu, X.; Jiao, B. Marine microbes-derived anti-bacterial agents. Mini Rev. Med. Chem. 2010, 10, 1077-1090.

28. Rahman, H.; Austin, B.; Mitchell, W.J.; Morris, P.C.; Jamieson, A.J.; Adams, D.R.; Spragg, A.M.; Schweizer, M. Novel anti-infective compounds from marine bacteria. Mar. Drugs 2010, 8, 498-518.

29. Suarez-Jimenez, G.M.; Burgos-Hernandez, A.; Ezquerra-Brauer. J.M. Bioactive peptides and depsipeptides with anticancer potential: Sources from marine animals. Mar. Drugs 2012, 10, 963-986.

30. Brinkman, D.L.; Aziz, A.; Loukas, A.; Potriquet, J.; Seymour, J.; Mulvenna, J. Venom proteome of the box jellyfish Chironex fleckeri. PLoS One 2012, 7, e47866.

31. Ovchinnikova, T.V.; Balandin, S.V.; Aleshina, G.M.; Tagaev, A.A.; Leonova, Y.F.; Krasnodembsky, E.D.; Men'shenin, A.V.; Kokryakov, V.N. Aurelin, a novel antimicrobial peptide from jellyfish Aurelia aurita with structural features of defensins and channel-blocking toxins. Biochem. Biophys. Res. Commun. 2006, 348, 514-523. 
32. Lee, J.U.; Kang, D.I.; Zhu, W.L.; Shin, S.Y.; Hahm, K.S.; Kim, Y.; Solution structures and biological functions of the antimicrobial peptide, arenicin-1, and its linear derivative. Biopolymers 2007, 88, 208-216.

33. Balandin, S.V.; Zhmak, M.N.; Kudelina, I.A.; Finkina, E.I.; Kokryakov, V.N.; Arseniev, A.S. Recombinant expression, synthesis, purification, and solution structure of arenicin. Biochem. Biophys. Res. Commun. 2007, 360, 1561-1562.

34. Desjardine, K.; Pereira, A.; Wright, H.; Matainaho, T.; Kelly, M.; Andersen, R.J. Tauramamide, a lipopeptide antibiotic produced in culture by Brevibacillus laterosporus isolated from a marine habitat: Structure elucidation and synthesis. J. Nat. Prod. 2007, 70, 1850-1853.

35. Huang, P.H.; Chen, J.Y.; Kuo, C.M. Three different hepcidins from tilapia, Oreochromis mossambicus: Analysis of their expressions and biological functions. Mol. Immunol. 2007, 44, 1922-1934.

36. Huang, W.S.; Wang, K.J.; Yang, M.; Cai, J.J.; Li, S.J.; Wang, G.Z. Purification and part characterization of a novel antibacterial protein scygonadin, isolated from the seminal plasma of mud crab, Scylla serrata (Forskal). J. Exp. Mar. Bio. Ecol. 2006, 339, 37-42.

37. Wang, K.J.; Huang, W.S.; Yang, M.; Chen, H.Y.; Bo, J.; Li, S.J.; Wang, G.Z. A malespecific expression gene, encodes a novel anionic antimicrobial peptide, scygonadin, in Scylla serrata. Mol. Immunol. 2007, 44, 1961-1968.

38. Cai, M.; Sugumaran, M.; Robinson, W.E. The crosslinking and antimicrobial properties of tunichrome. Comp. Biochem. Physiol. B Biochem. Mol. Biol. 2008, 151, 110-117.

39. Sugumaran, M.; Robinson, W.E. Structure, biosynthesis and possible function of tunichromes and related compounds. Comp. Biochem. Physiol. B Biochem. Mol. Biol. 2012, 163, 1-25.

40. Pettit, G.R.; Knight, J.C.; Herald, D.L.; Pettit, R.K.; Hogan, F.; Mukku, V.J.; Hamblin, J.S.; Dodson, M.J.; Chapuis, J.C. Antineoplastic agents. Isolation and structure elucidation of bacillistatins 1 and 2 from a marine Bacillus silvestris. J. Nat. Prod. 2009, 72, 366-371.

41. Engelhardt, K.; Degnes, K.F.; Kemmler, M.; Bredholt, H.; Fjaervik, E.; Klinkenberg, G.; Sletta, H.; Ellingsen, T.E.; Zotchev, S.B. Production of a new thiopeptide antibiotic, TP-1161, by a marine Nocardiopsis species. Appl. Environ. Microbiol. 2010, 76, 4969-4976.

42. Li, C.; Haug, T.; Moe, M.K.; Styrvold, O.B.; Stensvag, K. Centrocins: Isolation and characterization of novel dimeric antimicrobial peptides from the green sea urchin, Strongylocentrotus droebachiensis. Dev. Comp. Immunol. 2010, 34, 959-968.

43. Galinier, R.; Roger, E.; Sautiere, P.E.; Aumelas, A.; Banaigs, B.; Mitta, G. Halocyntin and papillosin, two new antimicrobial peptides isolated from hemocytes of the solitary tunicate, Halocynthia papillosa. J. Pept. Sci. 2009, 15, 48-55.

44. Sperstad, S.V.; Haug, T.; Vasskog, T.; Stensvag, K. Hyastatin, a glycine-rich multi-domain antimicrobial peptide isolated from the spider crab (Hyas araneus) hemocytes. Mol. Immunol. 2009, 46, 2604-2612.

45. Slightom, R.N.; Buchan, A. Surface colonization by marine roseobacters: Integrating genotype and phenotype. Appl. Environ. Microbiol. 2009, 75, 6027-6037.

46. Oku, N.; Kawabata, K.; Adachi, K.; Katsuta, A.; Shizuri, Y. Unnarmicins A and C, new antibacterial depsipeptides produced by marine bacterium Photobacterium sp. MBIC06485. J. Antibiot. 2008, 61, 11-17. 
47. Adachi, K.; Kawabata, Y.; Kasai, H.; Katsuta, M.; Shizuri, Y. Novel Ngercheumicin or its salt useful for treating infection caused by Pseudovibrio denitrificans. Japanese Patent JP2007230911-A, 13 September 2007.

48. Mansson, M.; Gram, L.; Larsen, T.O. Production of bioactive secondary metabolites by marine Vibrionaceae. Mar. Drugs 2011, 9, 1440-1468.

49. Rungprom, W.; Siwu, E.R.O.; Lambert, L.K.; Dechsakulwatana, C.; Barden, M.C.; Kokpol, U.; Blanchfield, J.T.; Kita, M.; Garson, M.J. Cyclic tetrapeptides from marine bacteria associated with the seaweed Diginea sp. and the sponge Halisarca ectofibrosa. Tetrahedron 2008, 64, 3147-3152.

50. Oku, N.; Adachi, K.; Matsuda, S.; Kasai, H.; Takatsaki, A.; Shizuri, Y. Ariakemicins A and B, novel polyketide-peptide antibiotics from a marine gliding bacterium of the genus Rapidithrix. Org. Lett. 2008, 10, 2481-2484.

51. Vidal-Dupiol, J.; Ladriere, O.; Destoumieux-Garzon, D.; Sautiere P.E.; Meistertzheim, A.L.; Tambutte, E.; Tambutte, S.; Duval, D.; Foure, L.; Adjeroud, M.; et al. Innate immune responses of a scleractinian coral to vibriosis. J. Biol. Chem. 2011, 286, 22688-22698.

52. Saude, A.C.; Ombredane, A.S.; Silva, O.N.; Barbosa, J.A.; Moreno, S.E.; Guerra Araujo, A.C.; Falcão, R.; Silva, L.P.; Dias, S.C.; Franco, O.L. Clavanin bacterial sepsis control using a novel methacrylate nanocarrier. Int. J. Nanomed. 2014, 9, 5055-5069.

53. Wang, W,; Kim, H.; Nam, S.J.; Rho, B.J.; Kang, H. Antibacterial butenolides from the Korean tunicate Pseudodistoma antinboja. J. Nat. Prod. 2012, 75, 2049-2054.

54. Beau, J.; Mahid. N.; Burda, W.N.; Harrington, L.; Shaw, L.N.; Mutka, T.; Kyle, D.E.; Barisic, B.; van Olphen, A.; Baker, B.J. Epigenetic tailoring for the production of anti-infective cytosporones from the marine fungus Leucostoma persoonii. Mar. Drugs 2012, 10, 762-774.

55. Jang, K.H.; Nam, S.J.; Locke, J.B.; Kauffman, C.A.; Beatty, D.S.; Paul, L.A.; Fenical, W. Anthracimycin, a potent anthrax antibiotic from a marine-derived actinomycete. Angew Chem. Int. Ed. Engl. 2013, 52, 7822-7824.

56. Jang, W.S.; Kim, H.K.; Lee, K.Y.; Kim, S.A.; Han, Y.S.; Lee, I.H. Antifungal activity of synthetic peptide derived from halocidin, antimicrobial peptide from the tunicate, Halocynthia aurantium. FEBS Lett. 2006, 580, 1490-1496.

57. D’Auria, M.V.; Sepe, V.; D’Orsi, R.; Bellotta, F.; Debitus, C.; Zampella, A. Isolation and structural elucidation of callipeltins J-M: Antifungal peptides from the marine sponge Latrunculia sp. Tetrahedron 2007, 63, 131-140.

58. Kunze, B.; Böhlendorf, B.; Reichenbach, H.; Höfle, G. Pedein A and B: Production, isolation, structure elucidation and biological properties of new antifungal cyclopeptides from Chondromyces pediculatus (Myxobacteria). J. Antibiot. 2008, 61, 18-26.

59. Nishimura, S.; Arita, Y.; Honda, M.; Iwamoto, K.; Matsuyama, A.; Shirai, A.; Kawasaki, H.; Kakeya, H.; Kobayashi, T.; Matsunaga, S.; et al. Marine antifungal theonellamides target 3ß-hydroxysterol to activate rho1 signaling. Nat. Chem. Biol. 2010, 6, 519-526.

60. Youssef, D.T.; Shaala, L.A.; Mohamed, G.A.; Badr, J.M.; Bamanie, F.H.; Ibrahim, S.R. Theonellamide G, a potent antifungal and cytotoxic bicyclic glycopeptide from the red sea marine sponge Theonella swinhoei. Mar. Drugs 2014, 12, 1911-1923. 
61. Plaza, A.; Bifulco, G.; Keffer, J.L.; Lloyd, J.R.; Baker, H.L.; Bewley, C.A. Celebesides A-C and theopapuamides B-D, depsipeptides from an indonesian sponge that inhibit HIV-1 entry. J. Org. Chem. 2009, 74, 504-512.

62. Berrue, F.; Ibrahim, A.; Boland, P.; Kerr, R.G. Newly isolated marine Bacillus pumilus (SP21): A source of novel lipoamides and other antimicrobial agents. Pure Appl. Chem. 2009, 81, 1027-1031.

63. Song, B.; Rong, Y.J.; Zhao, M.X.; Chi, Z.M. Antifungal activity of the lipopeptides produced by Bacillus amyloliquefaciens anti-CA against Candida albicans isolated from clinic. Appl. Microbiol. Biotechnol. 2013, 97, 7141-7150.

64. Zhang, D.J.; Liu, R.F.; Li, Y.G.; Tao, L.M.; Tian, L, Two new antifungal cyclic lipopeptides from Bacillus marinus B-9987. Chem. Pharm. Bull. (Tokyo) 2010, 58, 1630-1634.

65. Ma, Z.; Wang, N.; Hu, J.; Wang, S. Isolation and characterization of a new iturinic lipopeptide, mojavensin A produced by a marinederived bacterium Bacillus mojavensis B0621A. J. Antibiot. (Tokyo) 2012, 65, 317-322.

66. Gao, J.; Hamann, M.T. Chemistry and biology of kahalalides. Chem. Rev. 2011, 111, 3208-3235.

67. Iizuka, T.; Fudou, R.; Jojima, Y.; Ogawa, S.; Yamanaka, S.; Inukai, Y.; Ojika, M. Miuraenamides $\mathrm{A}$ and $\mathrm{B}$, novel antimicrobial cyclic depsipeptides from a new slightly halophilic myxobacterium: Taxonomy, production, and biological properties. J. Antibiot. 2006, 59, 385-391.

68. Ojika, M.; Inukai, Y.; Kito, Y.; Hirata, M.; Iizuka, T.; Fudou, R. Miuraenamides: Antimicrobial cyclic depsipeptides isolated from a rare and slightly halophilic myxobacterium. Chem. Asian J. 2008, 3, 126-133.

69. Ibrahim, S.R.; Min, C.C.; Teuscher, F.; Ebel, R.; Kakoschke, C.; Lin, W.; Wray, V.; Edrada-Ebel, R.; Proksch, P. Callyaerins A-F and H, new cytotoxic cyclic peptides from the Indionesian marine sponge Callyspongia aerizusa. Bioorg. Med. Chem. 2010, 18, 4947-4956.

70. McPhail, K.L.; Correa, J.; Linington, R.G.; Gonzalez, J.; Ortega-Barria, E.; Capson, T.L.; Gerwick, W.H., Antimalarial linear lipopeptides from a Panamanian strain of the marine cyanobacterium Lyngbya majuscula. J. Nat. Prod. 2007, 70, 984-988.

71. Linington, R.G.; Gonzalez, J.; Urena, L.D.; Romero, L.I.; Ortega-Barria, E.; Gerwick, W.H. Venturamides A and B: Antimalarial constituents of the Panamanian marine cyanobacterium Oscillatoria sp. J. Nat. Prod. 2007, 70, 397-401.

72. Portmann, C.; Blom, J.F.; Gademann, K.; Juttner, F. Aerucyclamides A and B: Isolation and synthesis of toxic ribosomal heterocyclic Peptides from the Cyanobacterium Microcystis aeruginosa PCC 7806. J. Nat. Prod. 2008, 71, 1193-1196.

73. Ziemert, N.; Ishida, K.; Quillardet, P.; Bouchier, C.; Hertweck, C.; de Marsac, N.T.; Dittmann, E. Microcyclamide biosynthesis in two strains of Microcystis aeruginosa: From structure to genes and Vice Versa. Appl. Environ. Microbiol. 2008, 74, 1791-1797.

74. Linington, R.G.; Clark, B.R.; Trimble, E.E.; Almanza, A.; Urena, L.D.; Kyle, D.E.; Gerwick, W.H. Antimalarial peptides from marine cyanobacteria: Isolation and structural elucidation of gallinamide A. J. Nat. Prod. 2009, 72, 14-17.

75. Tripathi, A.; Puddick, J.; Prinsep, M.R.; Rottmann, M.; Tan, L.T. Lagunamides A and B: Cytotoxic and antimalarial cyclodepsipeptides from the marine cyanobacterium Lyngbya majuscula. J. Nat. Prod. 2010, 73, 1810-1814. 
76. Carroll, A.R.; Nash, B.D.; Duffy, S.; Avery, V.M. Albopunctatone, an antiplasmodial anthrone-anthraquinone from the Australian ascidian Didemnum albopunctatum. J. Nat. Prod. 2012, 75, 1206-1209.

77. Simmons, T.L.; Engene, N.; Urena, L.D.; Romero, L.I.; Ortega-Barria, E.; Gerwick, L.; Gerwick, W.H. Viridamides A and B, lipodepsipeptides with antiprotozoal activity from the marine cyanobacterium Oscillatoria nigro-viridis. J. Nat. Prod. 2008, 71, 1544-1550.

78. Sanchez, L.M.; Lopez, D.; Vesely, B.A.; Della Togna, G.; Gerwick, W.H.; Kyle, D.E.; Linington, R.G. Almiramides A-C: Discovery and Development of a New Class of Leishmaniasis Lead Compounds. J. Med. Chem. 2010, 53, 4187-4197.

79. Pimentel-Elardo, S.M.; Kozytska, S.; Bugni, T.S.; Ireland, C.M.; Moll, H.; Hentschel, U. Anti-parasitic compounds from Streptomyces sp. strains isolated from mediterranean sponges. Mar. Drugs 2010, 8, 373-380.

80. Watts, K.R.; Ratnam, J.; Ang, K.H.; Tenney, K.; Compton, J.E.; McKerrow, J.; Crews, P. Assessing the trypanocidal potential of natural and semi-synthetic diketopiperazines from two deep water marine-derived fungi. Bioorg. Med. Chem. 2010, 18, 2566-2574.

81. Pruksakorn, P.; Arai, M.; Kotoku, N.; Vilcheze, C.; Baughn, A.D.; Moodley, P.; Jacobs, W.R., Jr.; Kobayashi, M. Trichoderins, novel aminolipopeptides from a marine sponge-derived Trichoderma sp., are active against dormant mycobacteria. Bioorg. Med. Chem. Lett. 2010, 20, 3658-3663.

82. Plaza, A.; Gustchina, E.; Baker, H.L.; Kelly, M.; Bewley, C.A. Mirabamides A-D, depsipeptides from the sponge Siliquariaspongia mirabilis that inhibit HIV-1 fusion. J. Nat. Prod. 2007, 70, 1753-1760.

83. Donia, M.S.; Wang, B.; Dunbar, D.C.; Desai, P.V.; Patny, A.; Avery, M.; Hamann, M.T. Mollamides B and C, cyclic hexapeptides from the Indonesian tunicate Didemnum molle. J. Nat. Prod. 2008, 71, 941-945.

84. Andjelic, C.; Planelles, V.; Barrows, L. Characterizing the anti-HIV activity of papuamide A. Mar. Drugs 2008, 6, 528-549.

85. Ratnayake, A.S.; Bugni, T.S.; Feng, X.; Harper, M.K.; Skalicky, J.J.; Mohammed, K.A.; Andjelic, C.D.; Barrows, L.R.; Ireland, C.M. Theopapuamide, a cyclic depsipeptide from a Papua New Guinea Lithistid sponge Theonella swinhoei. J. Nat. Prod. 2006, 69, 1582-1586.

86. He, F.; Bao, J.; Zhang, X.Y.; Tu, Z.C.; Shi, Y.M.; Qi, S.H. Asperterrestide A, a cytotoxic cyclic tetrapeptide from the marine-derived fungus Aspergillus terreus SCSGAF0162. J. Nat. Prod. 2013, 76, 1182-1186.

87. Zampella, A.; Sepe, V.; Bellotta, F.; Luciano, P.; D’Auria, M.V.; Cresteil, T.; Debitus, C.; Petek, S.; Poupat, C.; Ahond, A. Homophymines B-E and A1-E1, a family of bioactive cyclodepsipeptides from the sponge Homophymia sp. Org. Biomol. Chem. 2009, 7, 4037-4044.

88. Zampella, A.; Sepe, V.; Luciano, P.; Bellotta, F.; Monti, M.C.; D’Auria, M.V.; Jepsen, T.; Petek, S.; Adeline, M.-T.; Laprevote, O.; et al. Homophymine A, an anti-HIV cyclodepsipeptide from the sponge Homophymia sp. J. Org. Chem. 2008, 73, 5319-5327.

89. Araki, T.; Matsunaga, S.; Nakao, Y.; Furihata, K.; West, L.; Faulkner, D.J.; Fusetani, N. Koshikamide B, a cytotoxic peptide lactone from a marine sponge Theonella sp. J. Org. Chem. 2008, 73, 7889-7894. 
90. Plaza, A.; Bifulco, G.; Masullo, M.; Lloyd, J.R.; Keffer, J.L.; Colin, P.L.; Hooper, J.N.A.; Bell, L.J.; Bewley, C.A. Mutremdamide A and koshikamides C-H, peptide inhibitors of HIV-1 entry from different Thennella species. J. Org. Chem. 2010, 75, 4344-4355.

91. Bradshaw, J. Cationic antimicrobial peptides: Issues for potential clinical use. BioDrugs 2003, 17, 233-240.

92. Ovchinnikova, T.V.; Shenkarev, Z.O.; Balandin, S.V.; Nadezhdin, K.D.; Paramonov, A.S.; Kokryakov, V.N.; Arseniev, A.S. Molecular insight into mechanism of antimicrobial action of the beta-hairpin peptide arenicin: Specific oligomerization in detergent micelles. Biopolymers 2008, 89, 455-464.

93. Yederi, R.; Reddy, K. Purification and characterization of antibacterial proteins from granular hemocytes of Indian mud crab, Scylla serrata. Acta Biochim. Pol. 2009, 56, 71-82.

94. Cude, W.N.; Mooney, J.; Tavanaei, A.A.; Hadden, M.K.; Frank, A.M.; Gulvik, C.A.; May, A.L.; Buchan, A. Production of the antimicrobial secondary metabolite indigoidine contributes to competitive surface colonization by the marine roseobacter Phaeobacter sp. strain Y4I. Appl. Environ. Microbiol. 2012, 78, 4771-4780.

95. Dahiya, R.; Gautam, H. Toward the synthesis and biological screening of a cyclotetrapeptide from marine bacteria. Mar. Drugs 2011, 9, 71-81.

96. Binz, T.M.; Maffioli, S.I.; Sosio, M.; Donadio, S.; Muller, R. Insights into an unusual nonribosomal peptide synthetase biosynthesis. J. Biol. Chem. 2010, 285, 32710-32719.

97. Dahiya, R. Cyclopolypeptides with antifungal interest. Coll. Pharm. Commun. 2013, 1, 1-15.

98. Diehl, K.B. Topical Antifungal Agents: An Update. Am. Fam. Phys. 1996, 54, 1687-1692.

99. Onishi, J.; Meinz, M.; Thompson, J.; Curotto, J.; Dreikorn, S.; Rosenbach, M.; Douglas, C.; Abruzzo, G.; Tsipouras, A.; Wilson, K.; et al. Discovery of novel antifungal (1,3)-beta-D-glucan synthase inhibitors. Antimicrob. Agents Chemother. 2000, 44, 368-377.

100. Jang, W.S.; Kim, C.H.; Kang, M.S.; Chae, H.J.; Son, S.M.; Seo, S.J.; Lee, I.H. cDNA cloning of halocidin and a new antimicrobial peptide derived from the $\mathrm{N}$-terminus of Ci-META4. Peptides 2005, 26, 2360-2367.

101. Liu, X.; Ren, B.; Gao, H.; Liu, M.; Dai, H.; Song, F.; Yu, Z.; Wang, S.; Hu, J.; Kokare, C.R.; Zhang, L. Optimization for the production of surfactin with a new synergistic antifungal activity. PLoS One 2012, 7, e34430.

102. Shilabin, A.G.; Hamann, M.T. In vitro and in vivo evaluation of select kahalalide F analogs with antitumor and antifungal activities. Bioorg. Med. Chem. 2011, 19, 6628-6632.

103. World Health Organization. Available online: http://www.who.int/neglected_diseases/en/ (accessed on 14 October 2014).

104. Penet, M.F.; Kober, F.; Confort-Gouny, S.; Le Fur, Y.; Dalmasso, C.; Coltel, N.; Liprandi, A.; Gulian, J.M.; Grau, G.E.; Cozzone, P.J.; et al. Magnetic resonance spectroscopy reveals an impaired brain metabolic profile in mice resistant to cerebral malaria infected with Plasmodium berghei ANKA. J. Biol. Chem. 2007, 282, 14505-14514.

105. Snow, R.W.; Guerra, C.A.; Noor, A.M.; Myint, H.Y.; Hay, S.I. The global distribution of clinical episodes of Plasmodium falciparum malaria. Nature 2005, 434, 214-217.

106. Mishra, S.K.; Satpathy, S.K.; Mohanty, S. Survey of malaria treatment and deaths. Bull. World Health Organ. 1999, 77, 1020. 
107. Plebanski, M.; Locke, E.; Kazura, J.W.; Coppel, R.L. Malaria vaccines: Into a mirror, darkly? Trends Parasitol. 2008, 24, 532-536.

108. Schlitzer, M. Malaria chemotherapeutics part I: History of antimalarial drug development, currently used therapeutics, and drugs in clinical development. ChemMedChem 2007, 2, 944-986.

109. Schlitzer, M. Antimalarial drugs-what is in use and what is in the pipeline. Archiv. Der Pharmazie 2008, 341, 149-163.

110. Cheng, G.; Montero, A.; Gastaminza, P.; Whitten-Bauer, C.; Wieland, S.F.; Isogawa, M.; Fredericksen, B.; Selvarajah, S.; Gallay, P.A.; Ghadiri, M,R.; et al. A virocidal amphipathic alpha-helical peptide that inhibits hepatitis $\mathrm{C}$ virus infection in vitro. Proc. Natl. Acad. Sci. USA 2008, 105, 3088-3093.

111. Bai, F.; Town, T.; Pradhan, D.; Cox, J.; Ashish; Ledizet, M.; Anderson, J.F.; Flavell, R.A.; Krueger, J.K.; Koski, R.A.; et al. Antiviral peptides targeting the West Nile virus envelope protein. J. Virol. 2007, 81, 2047-2055.

112. Budge, P.J.; Graham, B.S. Inhibition of respiratory syncytial virus by RhoA-derived peptides: Implications for the development of improved antiviral agents targeting heparin-binding viruses. J. Antimicrob. Chemother. 2004, 54, 299-302.

113. Cooper, D.A.; Lange, J.M. Peptide inhibitors of virus-cell fusion: Enfuvirtide as a case study in clinical discovery and development. Lancet Infect. Dis. 2004, 4, 426-436.

114. Altmann, S.E.; Jones, J.C.; Schultz-Cherry, S.; Brandt, C.R. Inhibition of vaccinia virus entry by a broad spectrum antiviral peptide. Virology 2009, 388, 248-259.

115. Lu, Z.; van Wagoner, R.M.; Harper, M.K.; Baker, H.L.; Hooper, J.N.A.; Bewley, C.A.; Ireland, C.M. Mirabamides E-H, HIV-inhibitory depsipeptides from the sponge Stelletta clavosa. J. Nat. Prod. 2011, 74, 185-193.

116. Elyakova, L.A.; Vaskovsky, B.V.; Khoroshilova, N.I.; Vantseva, S.I.; Agapkina, Y.Y. Isolation and structure of a novel peptide inhibitor of HIV-1 integrase from marine polychaetes. Russ. J. Bioorg. Chem. 2011, 37, 207-216.

(C) 2015 by the authors; licensee MDPI, Basel, Switzerland. This article is an open access article distributed under the terms and conditions of the Creative Commons Attribution license (http://creativecommons.org/licenses/by/4.0/). 